1/19948\%(1)

SAND $94-1248$

Unlimited Release

UC-237 303

\title{
Twelve Month Performance Evaluation for the Rotating Shadowband Radiometer
}

Andrew L. Rosenthal, Jeffrey M. Roberg

New Mexico State University

Southwest Technology Development Institute

PO Box 30001/Dept. 3 SOLAR

Las Cruces, NM 88003-8001

Prepared by Sandia National Laboratories Albuquerque, New Mexico 87185

and Livermore, California 94550 for the United States Department of Energy under Contract DE-AC04-94AL85000

Approved for public release; distribution is unlimited.

Printed September 1994 
Issued by Sandia National Laboratories, operated for the United States Department of Energy by Sandia Corporation.

NOTICE: This report was prepared as an account of work sponsored by an agency of the United States Government. Neither the United States Government nor any agency thereof, nor any of their employees, nor any of their contractors, subcontractors, or their employees, makes any warranty, express or implied, or assumes any legal liability or responsibility for the accuracy, completeness, or usefulness of any information, apparatus, product, or process disclosed, or represents that its use would not infringe privately owned rights. Reference herein to any specific commercial product, process, or service by trade name, trademark, manufacturer, or otherwise, does not necessarily constitute or imply its endorsement, recommendation, or favoring by the United States Government, any agency thereof or any of their contractors or subcontractors. The views and opinions expressed herein do not necessarily state or reflect those of the United States Government, any agency thereof or any of their contractors.

Printed in the United States of America. This report has been reproduced directly from the best available copy.

Available to DOE and DOE contractors from Office of Scientific and Technical Information

PO Box 62

Oak Ridge, TN 37831

Prices available from (615) 576-8401, FTS 626-8401

Available to the public from

National Technical Information Service

US Department of Commerce

5285 Port Royal Rd

Springfield, VA 22161

NTIS price codes

Printed copy: A03

Microfiche copy: A01 


\section{DISCLAIMER}

Portions of this document may be illegible in electronic image products. Images are produced from the best available original document. 
SAND94-1248

Unlimited Release

Printed September 1994

\title{
Twelve Month Performance Evaluation for the Rotating Shadowband Radiometer
}

\author{
Andrew L. Rosenthal and Jeffrey M. Roberg \\ New Mexico State University \\ Southwest Technology Development Institute \\ PO Box 30001/Dept. 3 SOLAR \\ Las Cruces, NM 88003-8001
}

\begin{abstract}
The Southwest Technology Development Institute staff compared twelve months of 10-minute average data from a rotating shadowband radiometer (RSR) with data from three thermopile-based reference radiometers. Particular attention was focused on determining the accuracy of the direct normal irradiance data reported by the RSR. Accurate measurement of direct normal irradiance is the most critical requirement of the RSR when used for performance assessment of concentrating solar thermal collectors. Evaluation of three different methods of post-collection data processing was also performed.
\end{abstract}
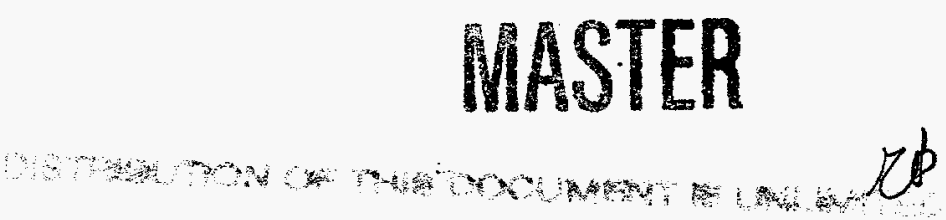



\section{TABLE OF CONTENTS}

$\underline{\text { Section }}$

Page

SUMMARY

$1.0 \quad$ INTRODUCTION

2.0 INSTRUMENTATION 2

2.1 Rotating Shadowband Radiometer ………….............................................. 2

2.2 Thermopile-based Reference Radiometers .......................................................... 4

2.3 Instrument Measurement Uncertainty Comparisons ...................................... 6

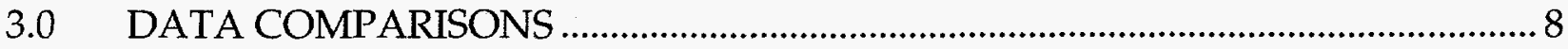

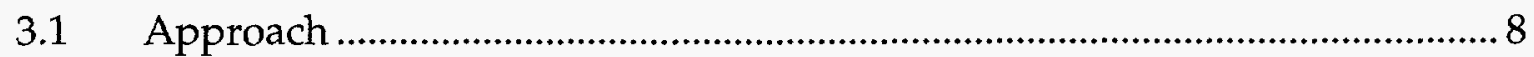

3.2 Global Horizontal Insolation ……………...................................................

3.3 Diffuse Horizontal Insolation ........................................................................... 11

3.4 Direct Normal Insolation ………………................................................. 13

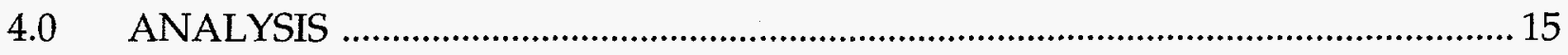

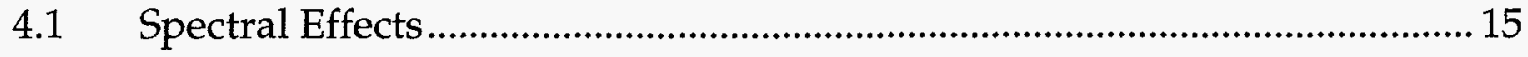

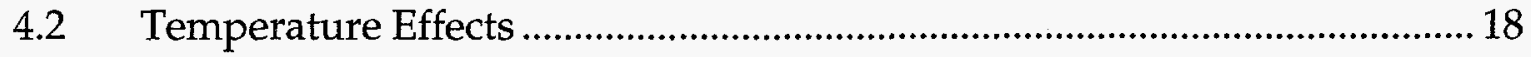

4.3 RSR Direct Normal Irradiance Data Remediation ........................................... 19

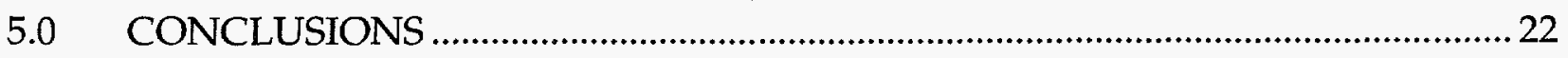

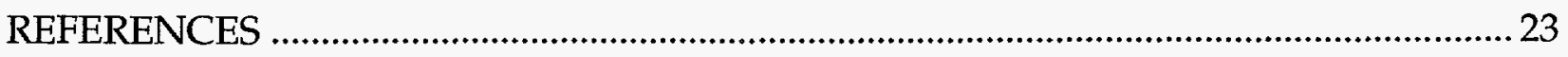




\section{LIST OF FIGURES AND TABLES}

Figure

Page

Figure 2-1. The Ascension Technologies, Inc., Rotating Shadowband Radiometer ........ 2

Figure 2-2. National Solar Thermal Test Facility Thermopile-based Reference Radiometers 5

Figure 3-1. Monthly Global Horizontal Insolation Sums and Differences ..................... 10

Figure 3-2. Global Horizontal Insolation RMS and Bias Differences ............................. 10

Figure 3-3. Monthly Diffuse Horizontal Insolation Sums and Differences ..................... 12

Figure 3-4. Diffuse Horizontal Insolation RMS and Bias Differences ............................ 12

Figure 3-5. Monthly Direct Normal Insolation Sums and Differences .......................... 13

Figure 3-6. Direct Normal Insolation RMS and Bias Differences ..................................... 14

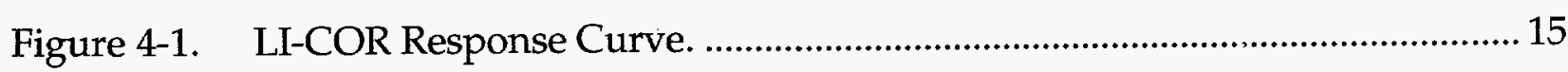

Figure 4-2. Clear Day Global and Diffuse Horizontal Irradiance .................................. 17

Figure 4-3. Effects of Temperature on LI-COR Response.............................................. 18

Table

Page

Table S-1. Rotating Shadowband Radiometer/Reference Radiometer 10-Minute Data Comparison Summary

Table S-2. Rotating Shadowband Radiometer/Reference Radiometer 1993 Insolation Comparison Summary

Table 2-1. Cost Comparison of RSR and Reference Radiometers ................................... 4

Table 2-2. Thermopile-based Reference Radiometers ........................................................

Table 2-3. Measurement Uncertainty Estimates (From Stoffel, 1991) ..............................

Table 3-1. Rotating Shadowband Radiometer/Reference Radiometer Monthly Insolation Comparison Summary

Table 3-2. Rotating Shadowband Radiometer/Reference Radiometer 10-Minute Data Comparison Summary

Table 4-1. Parameters Influencing Global Spectral Distribution ...................................... 16

Table 4-2. Direct Normal Irradiance Correction Algorithm Comparison..................... 20 


\section{SUMMARY}

The rotating shadowband radiometer (RSR) is a single instrument that uses a silicon detector to make direct measurements of solar global horizontal irradiance $\left(G_{h}\right)$ and diffuse horizontal irradiance $\left(D_{h}\right)$ and provides calculated values for direct normal irradiance $\left(I_{d}\right)$. This report evaluates the RSR as a measurement instrument for use in performance assessment of concentrating solar thermal collectors.

For twelve months, 10-minute average data were collected from a RSR and, for comparison, from three thermopile-based radiometers located at the National Solar Thermal Test Facility (NSTTF) at Sandia National Laboratories (SNL) in Albuquerque, New Mexico. The data were analyzed as follows: 1) to quantify and explain the measurement uncertainties and inaccuracies associated with the data reported by the RSR, particularly the $I_{d}$ data; and 2) to assess the long-term reliability of the RSR in field use.

The reliability and availability of the RSR were excellent. No operator intervention, repair, or realignment was required for normal use. However, the internal clock, which the RSR uses for calculation of the solar ephemeris, can drift as much as one minute per month. To prevent this, the clock was reset via modem each week throughout the test period to agree with time provided by the Naval Observatory in Washington, D.C.

Accurate short-term measurements are required for determination of real-time efficiency of concentrating solar thermal collectors. Table S-1 presents an overview of the accuracy of the RSR in measuring irradiance during 10-minute periods. The rootmean square (RMS) difference is the magnitude of the difference between each 10minute RSR and reference radiometer reading (regardless of sign) averaged over a month. The bias value indicates the magnitude and sign of consistent, systematic differences between the RSR and reference radiometer readings determined for each month. All differences are expressed as percentages in Table S-1.

The RSR measured $\mathrm{G}_{\mathrm{h}}$ with an average monthly RMS difference of $4.3 \%$ (compared to the reference radiometer). The bias difference in these data was $-0.4 \%$ indicating that the RSR roughly equally overestimated and underestimated the global irradiance each month. 


\section{Table S-1. Rotating Shadowband Radiometer/Reference Radiometer 10-Minute Data Comparison Summary}

$\begin{array}{lccc} & \begin{array}{c}\text { Mean Monthly } \\ \text { RMS Difference (\%) }\end{array} & \begin{array}{c}\text { Median Monthly } \\ \text { RMS Difference (\%) }\end{array} & \begin{array}{c}\text { Mean Monthly } \\ \text { Bias Difference (\%) }\end{array} \\ \text { Global Horizontal } & 4.3 & 3.8 & -0.4 \\ \text { Diffuse Horizontal } & 12.5 & 11.5 & -7.0 \\ \text { Direct Normal } & 5.6 & 5.9 & 3.4\end{array}$

The RSR $D_{h}$ data were consistently lower than the reference readings, displaying an average monthly bias error of $-7.0 \%$. The predominant reason for this is attributed to the selective spectral response of the RSR's silicon detector pyranometer and differences between the spectral distribution of diffuse irradiance and the global irradiance under which this pyranometer is calibrated (see text).

Accurate measurement of direct normal irradiance is the most critical requirement of the RSR in concentrating solar collector characterization. In determination of $I_{d}$, the RSR and reference radiometer data displayed average monthly RMS and bias differences of $5.6 \%$ and $3.4 \%$, respectively. Since the RSR calculates $I_{d}$ by taking the difference between the global and diffuse readings (corrected for solar zenith angle), consistent underestimation of the diffuse irradiance gave rise to overestimation of the calculated direct normal irradiance. It is possible to improve the accuracy of these readings with post collection processing. ATI makes use of algorithms that correct raw readings based on temperature and solar zenith angle after the work of Michalsky, et. al. (15). For comparison, two additional correction procedures are proposed in the text: 1) a simple subtraction of the bias; and 2) a correction algorithm based on solar zenith angle only. All three procedures effectively reduce bias in the data and average RMS errors.

The RSR was also evaluated in its performance of general purpose solar resource assessment. Data were compiled into monthly and yearly totals and the accuracy of these figures was determined. Table S-2 presents the yearly insolation totals recorded by the RSR and reference radiometers for the three irradiance components. The percentage differences between these yearly figures are shown. 
Table S-2. Rotating Shadowband Radiometer/Reference Radiometer 1993 Insolation Comparison Summary

\begin{tabular}{|c|c|c|c|c|c|c|c|c|}
\hline \multicolumn{3}{|c|}{ Global Horizontal } & \multicolumn{3}{|c|}{ Diffuse Horizontal } & \multicolumn{3}{|c|}{ Direct Normal } \\
\hline $\begin{array}{c}\text { RSR } \\
\text { (kWh) }\end{array}$ & $\begin{array}{l}\text { Ref. } \\
\text { (kWh) }\end{array}$ & $\begin{array}{c}\text { Diff. } \\
\text { (\%) }\end{array}$ & $\begin{array}{c}\text { RSR } \\
\text { (kWh) }\end{array}$ & $\begin{array}{l}\text { Ref. } \\
\text { (kWh) }\end{array}$ & $\begin{array}{l}\text { Diff. } \\
(\%)\end{array}$ & $\begin{array}{c}\text { RSR } \\
\text { (kWh) }\end{array}$ & $\begin{array}{l}\text { Ref. } \\
\text { (kWh) }\end{array}$ & $\begin{array}{l}\text { Diff. } \\
\text { (\%) }\end{array}$ \\
\hline 1906.4 & 1920.2 & -0.7 & 508.6 & 548.9 & -7.2 & 2351.0 & 2277.5 & 3.3 \\
\hline
\end{tabular}




\subsection{INTRODUCTION}

A rotating shadowband radiometer (RSR) has been in operation at the National Solar Thermal Test Facility (NSTTF) at Sandia National Laboratories (SNL) in Albuquerque, New Mexico, since the latter part of 1992. Since its installation, the Southwest Technology Development Institute (TDI) has been collecting and archiving the data generated by the RSR. This report summarizes the solar measurement data obtained with this instrument during the 12-month period from January through December 1993 and compares these data with similar data obtained from three first-class thermopilebased radiometers at the same location.

The RSR under test is a commercially available instrument manufactured by Ascension Technology, Inc. (ATI, Waltham, MA). The sensing element is a silicon detector pyranometer (LI-COR model LI-200SZ).

For this study, measurements were taken every minute and averaged over 10-minute periods for both the RSR and the thermopile instruments. This report examines the collected data and assesses both the short-term and long-term accuracy of the global horizontal, diffuse horizontal, and direct normal irradiance data generated by the RSR.

Short-term accuracy is an essential requirement for tasks such as determining the efficiency of a concentrating solar thermal or photovoltaic (PV) collector. In this report, short-term accuracy refers to the accuracy of the 10-minute average data points.

Errors that are randomly caused or periodic in nature can be large in the short-term but self-canceling in the long-term. A task such as solar resource assessment requires accuracy only in the long-term data; instantaneous inaccuracies are of little consequence. To this end, the data were compiled into monthly and yearly totals. The accuracy of these figures was also assessed.

Performance studies of the ATI RSR by NREL/EPRI and ATI have been published elsewhere $(\underline{3}, \underline{7})$. These studies have addressed the use of the RSR for general resource assessment. This report addresses the use of the RSR for performance characterization of concentrating solar thermal collectors. 


\subsection{INSTRUMENTATION}

\subsection{Rotating Shadowband Radiometer}

Ascension Technologies, Inc. (ATI, Waltham, MA) developed its model of a rotating shadowband radiometer (RSR) in 1990 under contract with the New York Power Authority (3). In August of 1992, an ATI RSR was installed at the National Solar Thermal Test Facility (NSTTF) at Sandia National Laboratories (SNL) in Albuquerque, New Mexico. Since that time, the Southwest Technology Development Institute (TDI) has been collecting data from the RSR via modem and archiving the data:

The RSR is a single instrument that provides direct measurements of global and diffuse irradiance and calculated values for direct normal irradiance. Figure 2-1 shows the ATI RSR.

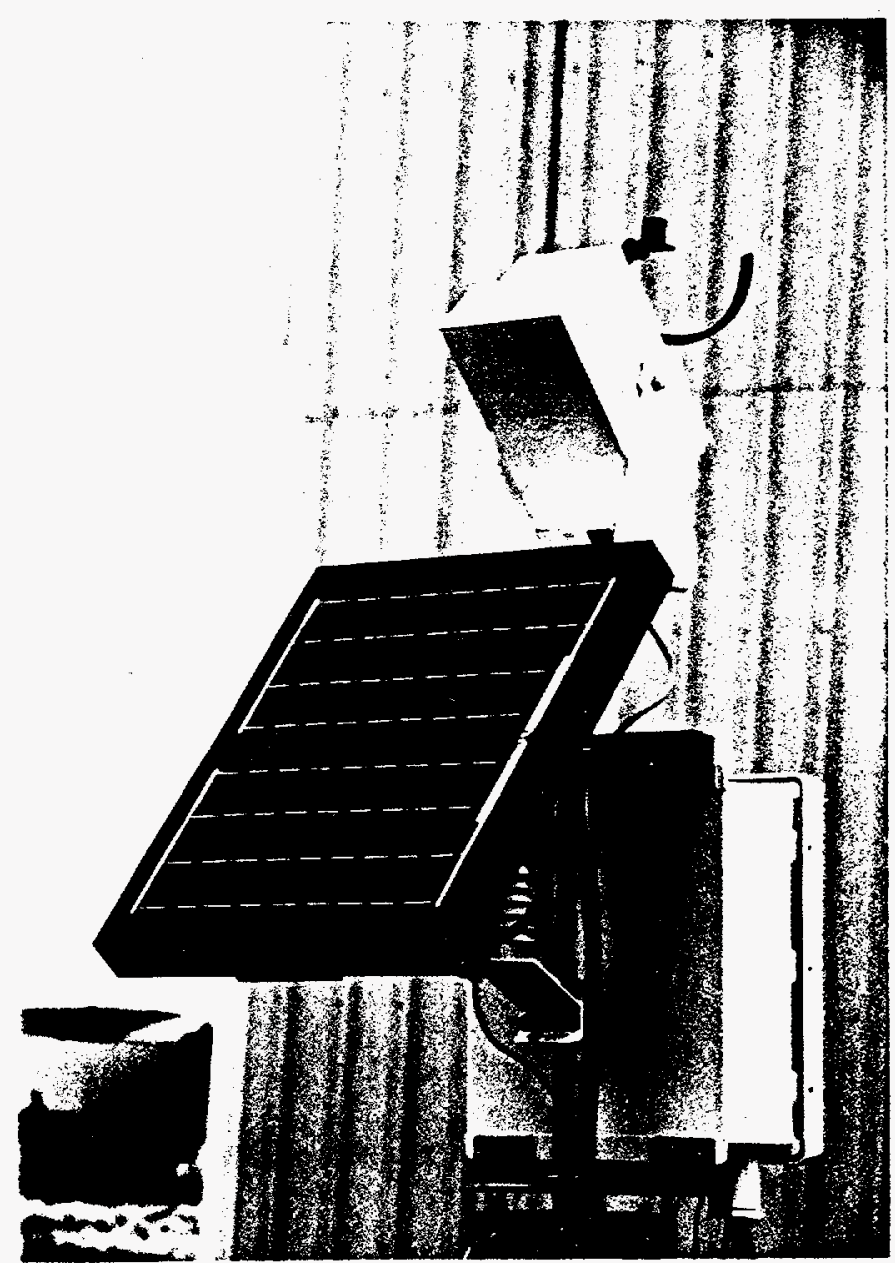

Figure 2-1. The Ascension Technologies, Inc., Rotating Shadowband Radiometer 
The major mechanical components of the RSR are:

1. LI-COR model LI-200SZ silicon detector pyranometer, mounted in a horizontal plane, used for the measurement of global and diffuse radiation

2. motor-driven, curved, aluminum shadowband

3. photovoltaic power supply ( $18 \mathrm{~W}$ PV module, battery charge controller, 31 A-h lead-acid battery)

4. Campbell Scientific, Inc., CR-10 datalogger for control of the shadowband and data acquisition

5. Nema-4 fiberglass enclosure

The datalogger is software driven and pre-programmed with the latitude and longitude of the RSR's location. The datalogger has an on-board clock/calendar circuit so that real-time solar position can be calculated based on site coordinates, time, and date.

In operation, the RSR works as follows. The global horizontal irradiance is measured once per second using the pyranometer in a conventional way. Fifty-four seconds into each minute, the datalogger switches on the motor to rotate the shadowband once completely around the pyranometer. During this rotation, the datalogger acquires data at a high sample rate in order to ensure that the null associated with maximum shading is recorded. This null provides measurement of the diffuse irradiance. The datalogger then calculates the current solar zenith angle based upon time of day, date, and site coordinates using equations that model the motion of the sun. Having derived the solar zenith angle, the direct normal irradiance is calculated using the radiation component equation:

$$
\mathrm{G}_{\mathrm{h}}=\mathrm{D}_{\mathrm{h}}+\mathrm{I}_{\mathrm{d}} \cos (z)
$$

where $G_{h}$ is global horizontal irradiance, $D_{h}$ is the diffuse horizontal irradiance, $I_{d}$ is the direct normal irradiance, and $z$ is the solar zenith angle. At the end of each 10-minute period, the ten 1-minute data points for each irradiance component are averaged and recorded.

In comparison with the reference, thermopile-based instruments, the RSR has some desirable features:

- Some studies indicate that silicon detector pyranometers have greater tolerance to the effects of soiling than do thermopile radiometers ( $\underline{4})$. 
- The increased stability of the silicon detector results in a recommended period of recalibration that is twice as long as required by the thermopile instruments (two years versus one year).

In addition, there is a cost savings associated with the purchase of the RSR. Table 2-1 shows the current (1994) prices for the RSR and reference radiometers used in this study.

Table 2-1. Cost Comparison of RSR and Reference Radiometers ROTATING SHADOWBAND RADIOMETER

Measurement

Direct Normal ATI RSR

Instrument $\quad$ Cost

$\$ 5,700$

REFERENCE RADIOMETERS

Measurement $\quad \underline{\text { Instrument }}$

Global Horizontal

Eppley Precision Spectral Pyranometer (PSP)

Cost

Diffuse Horizontal Eppley PSP with Eppley Shadow Band Stand

$\$ 1,975$

Direct Normal Eppley (Normal Incidence Pyrheliometer) NIP $\$ 3,550$ with Eppley ST-3 Solar Tracker

$\$ 10,200$

The RSR is not without some undesirable features. Among these are:

- The silicon detector is spectrally and temperature sensitive. In the RSR under test, no corrections are made for this which leads to measurement uncertainties.

- $\quad$ Accurate time must be kept to ensure proper calculation of the solar zenith angle and direct normal irradiance. Unattended, the datalogger clock can drift up to one minute per month. The need to regularly (weekly) reset the datalogger clock prohibits its use in sites without two-way (e.g. telephone) communications.

\subsection{Thermopile-based Reference Radiometers}

Three thermopile-based radiometers were used to provide reference readings for RSR comparisons. All three of the reference instruments meet the criteria listed for first class designation according to the specifications set by the World Meteorological Organization (1965). Figure 2-2 shows the reference radiometers in use at the NSTTF. The instruments are described in Table 2-2. 


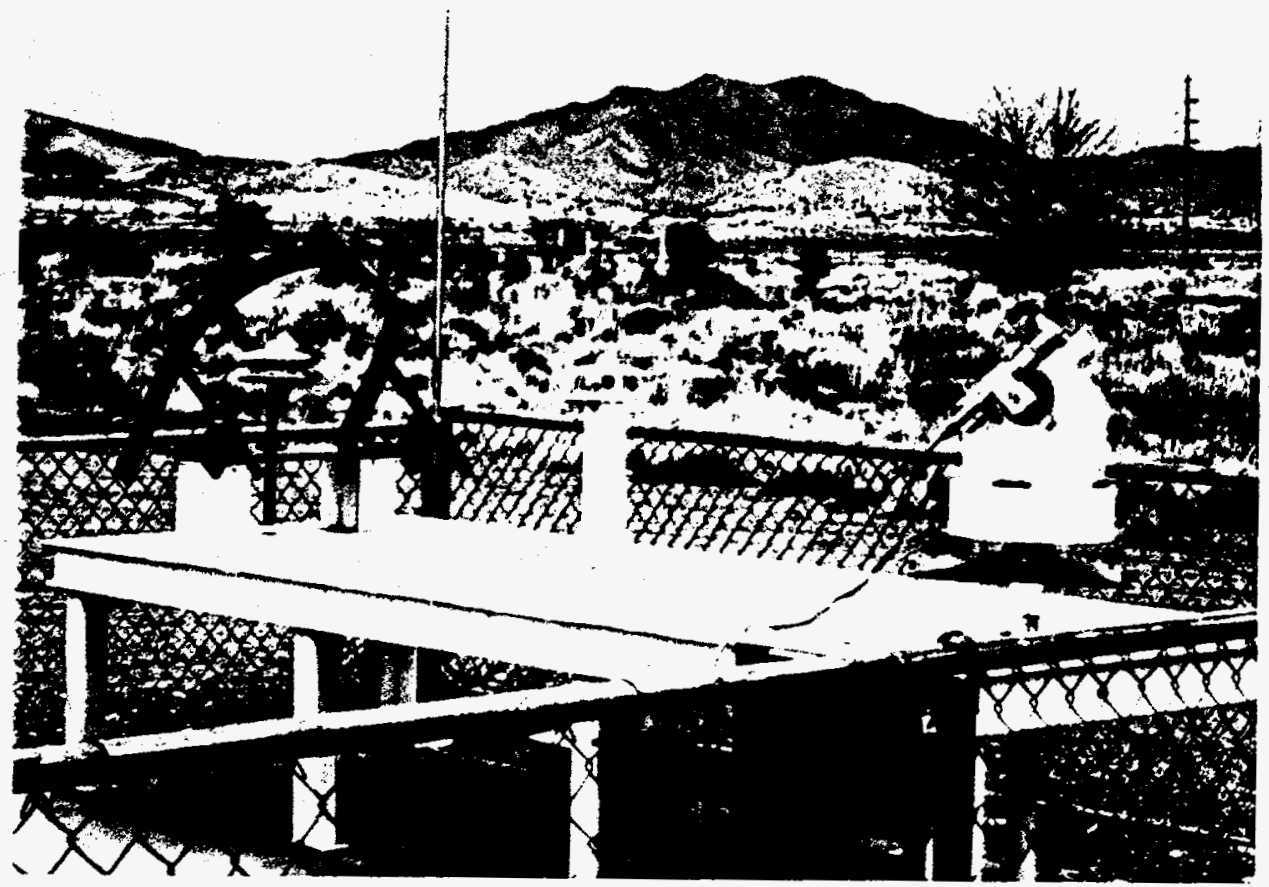

Figure 2-2. National Solar Thermal Test Facility

Thermopile-based Reference Radiometers

Table 2-2. Thermopile-based Reference Radiometers

Global Horizontal

Diffuse Horizontal

Eppley Precision Spectral Pyranometer (PSP)

Direct Normal

Eppley PSP with Eppley Shadow Band Stand

Eppley Normal Incidence Pyrheliometer (NIP)

with Eppley ST-3 automatic Solar Tracker

The Eppley precision spectral pyranometer (PSP) uses a circular multi-junction thermopile to measure the temperature rise in a black, non-wavelength selective, $1 \mathrm{~cm}^{2}$ receiver. The PSP is temperature and cosine response corrected. The manufacturer specifies that accuracy is within $\pm 1 \%$ for operation over the temperature range -20 to $+40^{\circ} \mathrm{C}$ and $\pm 1 \%$ for incidence angles between 0 and $70^{\circ}$. In the field, however, these instruments often demonstrate deviations with temperature and solar incidence angle in excess of these specifications $(\underline{5}, \underline{8})$.

For purposes of comparison with the RSR, therefore, the reference global horizontal irradiance used throughout this report was derived (according to equation 2.0) from the measured direct normal and diffuse horizontal (corrected per equation 2.1, below) irradiances. The section that follows (2.3) describes some of the major sources of 
measurement uncertainty associated with the use of the various radiometers. As shown in that section, the uncertainty for calculated global horizontal irradiance (based on NIP and PSP/SBS data) is approximately half of that for the PSP measurement alone.

The reference diffuse horizontal irradiance was measured using an Eppley PSP and Eppley Shadow Band Stand (SBS). The SBS requires and received daily adjustment to provide proper shading of the pyranometer. Eppley provides a table of monthly shadowband correction factors (SBCF) for use with the SBS. For this study, a more accurate SBCF was determined (see references $\underline{Z}, \underline{2}$ ) and applied to each 10-minute diffuse reading prior to any use of the data. The shadowband correction factor was calculated as follows:

$$
\operatorname{SBCF}=1.04 *\left(1+(w / r) * \cos ^{3} d *(\sin j \sin d+\cos j \cos d \cos h)\right)
$$

where $w$ is the shadow band's width and $r$ is its radius, $d$ is the declination, $j$ is the site latitude, and $h$ is the hour angle.

The direct normal irradiance was measured with an Eppley normal incidence pyrheliometer (NIP). The NIP is mounted on an Eppley ST-3 solar tracker. Properly installed, this fully-automatic solar tracker requires no realignment to accurately follow the sun.

All three thermopile radiometers receive yearly recalibration. During the test period, these instruments and the RSR LI-COR were recalibrated during the last week of March, 1993.

\subsection{Instrument Measurement Uncertainty Comparisons}

Some uncertainty and inaccuracy is a part of every radiometer measurement. Estimates of the magnitude of these values are presented in Table 2-3. Table 2-3 is taken from Stoffel, et. al. (Z), and lists reasonable estimates of the measurement uncertainties inherent in the use of the various radiometers included in this report. Before examining the data, it is important to understand the measurement uncertainties associated with the use of each radiometer. These uncertainties give an indication of the magnitude of the measurement inaccuracies possible even when the radiometer involved is correctly calibrated and properly operated. 
Table 2-3. Measurement Uncertainty Estimates (From Stoffel, 1991).

\begin{tabular}{|c|c|c|c|c|c|c|c|}
\hline Instrument & $\begin{array}{l}\text { Instru. } \\
\text { Calib. } \\
\text { Uncert. }\end{array}$ & $\begin{array}{l}\text { Level/ } \\
\text { Track. } \\
\text { Uncert. }\end{array}$ & $\begin{array}{l}\text { Uncert. } \\
\text { due to } \\
\text { Timing }\end{array}$ & $\begin{array}{l}\text { S-Band } \\
\text { Corr. } \\
\text { Uncert. }\end{array}$ & $\begin{array}{l}\text { Spectral } \\
\text { Uncert. }\end{array}$ & $\begin{array}{l}\text { Direct./ } \\
\text { Temp. } \\
\text { Uncert. }\end{array}$ & $\begin{array}{c}\text { Total } \\
\text { Uncertainty }\end{array}$ \\
\hline RSR: Horizontal & $\pm 4.9 \%$ & $\pm 1.3 \%$ & & & $\pm 1.0 \%$ & $\pm 3.7 \%$ & $\pm 6.4 \%$ \\
\hline RSR: Diffuse & $\pm 4.9 \%$ & $\pm 1.3 \%$ & & $\pm 1.0 \%$ & $\pm 1.0 \%$ & $\pm 3.7 \%$ & $\pm 6.6 \%$ \\
\hline RSR: Direct Norm. & & & $\pm 1.0 \%$ & & & & $\pm 6.5 \%$ \\
\hline PSP: Horizontal & $\pm 4.0 \%$ & $\pm 1.3 \%$ & & & $\pm 0.2 \%$ & $\pm 1.7 \%$ & $\pm 4.0 \%$ \\
\hline Calc. Horizontal & & & $\pm 1.0 \%$ & & & & $+2.4 \%$ \\
\hline PSP/SBS: Diffuse & $\pm 3.6 \%$ & $\pm 1.3 \%$ & & $\pm 2.0 \%$ & $\pm 0.2 \%$ & $\pm 1.7 \%$ & $\pm 4.8 \%$ \\
\hline NIP: Direct Norm. & $\pm 1.8 \%$ & $\pm 0.02 \%$ & & & $\pm 0.1 \%$ & $\pm 1.0 \%$ & $\pm 2.1 \%$ \\
\hline
\end{tabular}

The data analysis performed during this study largely support the figures in Table 2-3 with one exception. The spectral effects on RSR diffuse measurement uncertainties were found to be several times larger than the $\pm 1 \%$ given in the table. This is presented in detail in the Analysis section, below.

Though measurement uncertainties for the reference instruments are smaller in magnitude than those for the RSR, they are not zero. Depending on the sign and magnitude of these uncertainties, inaccuracies in the reference readings can act to minimize some of the differences observed between the reference instruments and the RSR or make them larger. 


\subsection{DATA COMPARISONS}

\subsection{Approach}

Two different approaches to data analysis were taken in this study. The first approach was to sum the 10-minute data into long-term data sets and to analyze these. In this report, monthly and yearly sums of global horizontal, direct, and diffuse horizontal insolation were calculated for comparison of the RSR and reference radiometer measurements. This approach mitigates the effects of random or periodic errors, which are largely self-canceling in the long-term. A task such as general purpose resource assessment usually requires accuracy only in the long-term data. Table 3-1 presents the monthly and yearly sums of the irradiance components recorded by the RSR and reference radiometers.

Table 3-1. Rotating Shadowband Radiometer/Reference Radiometer Monthly Insolation Comparison Summary

\begin{tabular}{lrcrrrrrrr} 
& \multicolumn{3}{c}{ Global Horizontal } & \multicolumn{2}{c}{ Diffuse Horizontal } & \multicolumn{3}{c}{ Direct Normal } \\
& $\begin{array}{c}\text { RSR } \\
(\mathbf{k W h})\end{array}$ & $\begin{array}{c}\text { Ref. } \\
\mathbf{( k W h )}\end{array}$ & $\begin{array}{c}\text { Diff. } \\
\mathbf{( \% )}\end{array}$ & $\begin{array}{c}\text { RSR } \\
\mathbf{( k W h )}\end{array}$ & $\begin{array}{c}\text { Ref. } \\
\mathbf{( k W h )}\end{array}$ & $\begin{array}{c}\text { Diff. } \\
\mathbf{( \% )}\end{array}$ & $\begin{array}{c}\text { RSR } \\
\mathbf{( k W h )}\end{array}$ & $\begin{array}{c}\text { Ref. } \\
\mathbf{( k W h )}\end{array}$ & $\begin{array}{c}\text { Diff. } \\
\mathbf{( \% )}\end{array}$ \\
Jan & 81.1 & 80.4 & 0.8 & 38.0 & 38.2 & -0.6 & 103.1 & 100.7 & 2.4 \\
Feb & 97.8 & 97.7 & 0.2 & 47.2 & 48.6 & -2.9 & 104.2 & 100.3 & 3.9 \\
Mar & 161.3 & 161.8 & -0.3 & 48.3 & 50.4 & -4.0 & 196.1 & 190.3 & 3.1 \\
Apr & 206.6 & 209.6 & -1.4 & 58.1 & 62.7 & -7.3 & 223.2 & 216.7 & 3.0 \\
May & 220.4 & 223.3 & -1.3 & 63.0 & 68.6 & -8.2 & 221.7 & 216.6 & 2.4 \\
Jun & 235.6 & 239.0 & -1.4 & 48.6 & 55.7 & -12.8 & 268.0 & 261.1 & 2.6 \\
Jul & 178.9 & 181.3 & -1.3 & 28.9 & 34.3 & -15.8 & 212.0 & 206.4 & 2.7 \\
Aug & 190.0 & 192.5 & -1.3 & 60.8 & 66.6 & -8.8 & 183.2 & 177.0 & 3.5 \\
Sep & 188.2 & 190.9 & -1.5 & 29.0 & 33.9 & -14.5 & 266.2 & 257.4 & 3.5 \\
Oct & 145.1 & 145.9 & -0.5 & 34.8 & 37.3 & -6.7 & 211.0 & 202.6 & 4.2 \\
Nov & 109.1 & 108.1 & 1.0 & 25.9 & 26.6 & -2.7 & 192.0 & 184.3 & 4.2 \\
Dec & 92.3 & 89.8 & 2.9 & 26.1 & 26.1 & 0.2 & 172.4 & 164.1 & 5.1 \\
Year & 1906.4 & 1920.2 & -0.7 & 508.6 & 548.9 & -7.2 & 2351.0 & 2277.5 & 3.3
\end{tabular}


The second approach to analysis of the data measured the short-term accuracy of the RSR in its agreement with the data recorded by the reference instruments. Statistics based on each 10-minute data point recorded by the RSR and the reference radiometers were used for this task. Monthly and yearly sums do not provide the resolution necessary for performance characterization of concentrating solar collectors. Short-term accuracy is required where the 10-minute readings are individually used for efficiency or performance assessment of concentrating solar thermal or PV systems. In this report, the root-mean-square (RMS) difference and the bias difference were used to assess agreement between the 10 -minute averages recorded by any two instruments. The RMS difference indicates the magnitude of the average difference between the two data sets (regardless of sign). The bias difference reveals whether or not one instrument reads consistently higher or lower than the other and by what magnitude. Table 3-2 provides a statistical comparison of the RSR and reference radiometer short-term data.

\section{Table 3-2. Rotating Shadowband Radiometer/Reference Radiometer 10-Minute Data Comparison Summary}

$\begin{array}{lccc} & \begin{array}{c}\text { Mean Monthly } \\ \text { RMS Difference (\%) }\end{array} & \begin{array}{c}\text { Median Monthly } \\ \text { RMS Difference (\%) }\end{array} & \begin{array}{c}\text { Mean Monthly } \\ \text { Bias Difference (\%) }\end{array} \\ \text { Global Horizontal } & 4.3 & 3.8 & -0.4 \\ \text { Diffuse Horizontal } & 12.5 & 11.5 & -7.0 \\ \text { Direct Normal } & 5.6 & 5.9 & 3.4\end{array}$

The three following sections compare the global horizontal, diffuse horizontal, and direct normal irradiance data recorded by the RSR and reference radiometers.

\subsection{Global Horizontal Insolation}

Figure 3-1 presents monthly sums of the global horizontal insolation recorded by the RSR (i.e. the LI-COR pyranometer) and the reference, calculated global horizontal insolation (derived from measurements of the NIP and PSP/SBS). Also shown in the figure are the percentage differences between the monthly figures. 


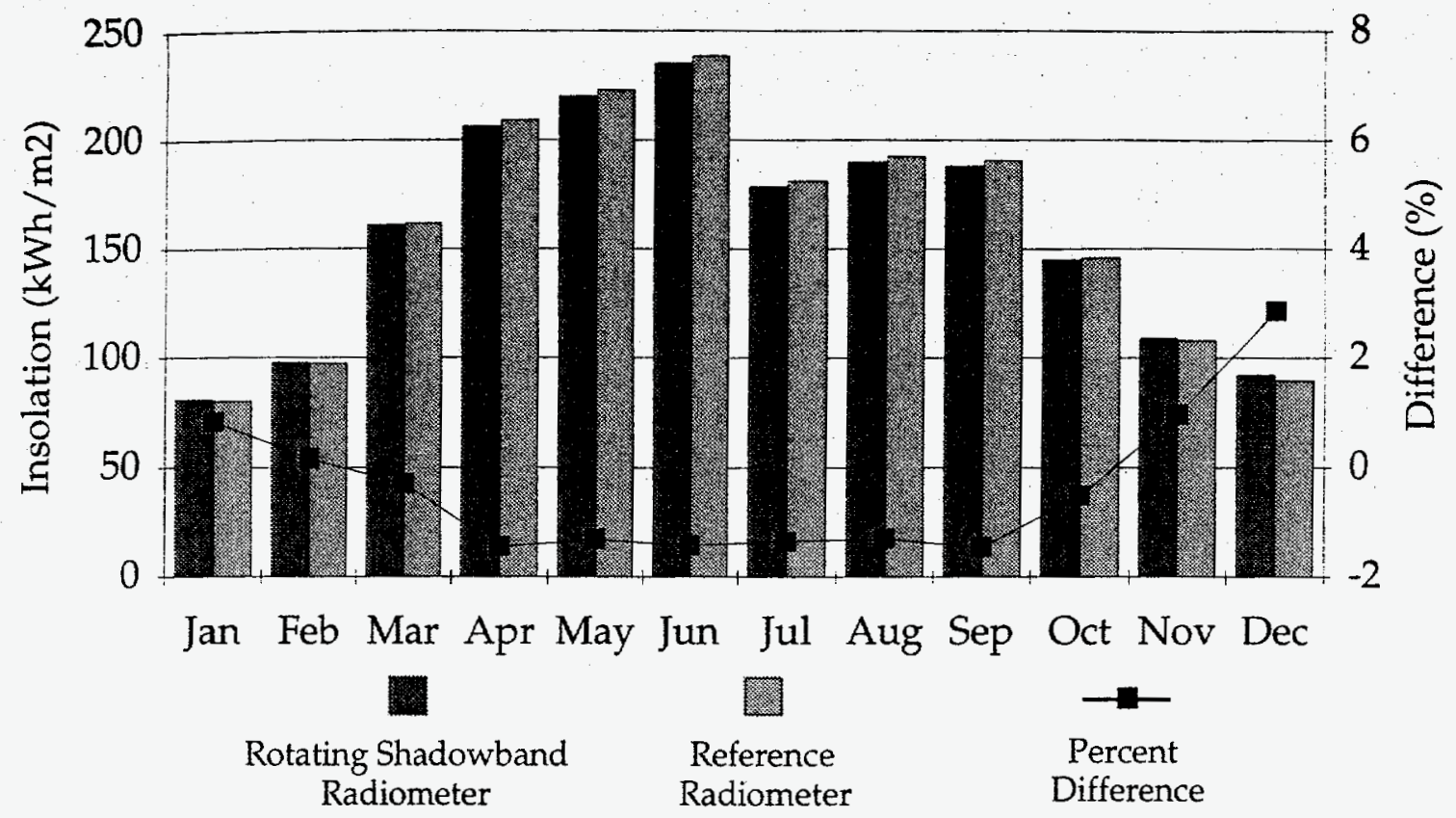

Figure 3-1. Monthly Global Horizontal Insolation Sums and Differences

Figure 3-2 shows the RMS and bias differences observed between the 10-minute RSR and reference global horizontal data sets. These differences were calculated for each $10-$ minute data pair and then averaged over monthly periods.

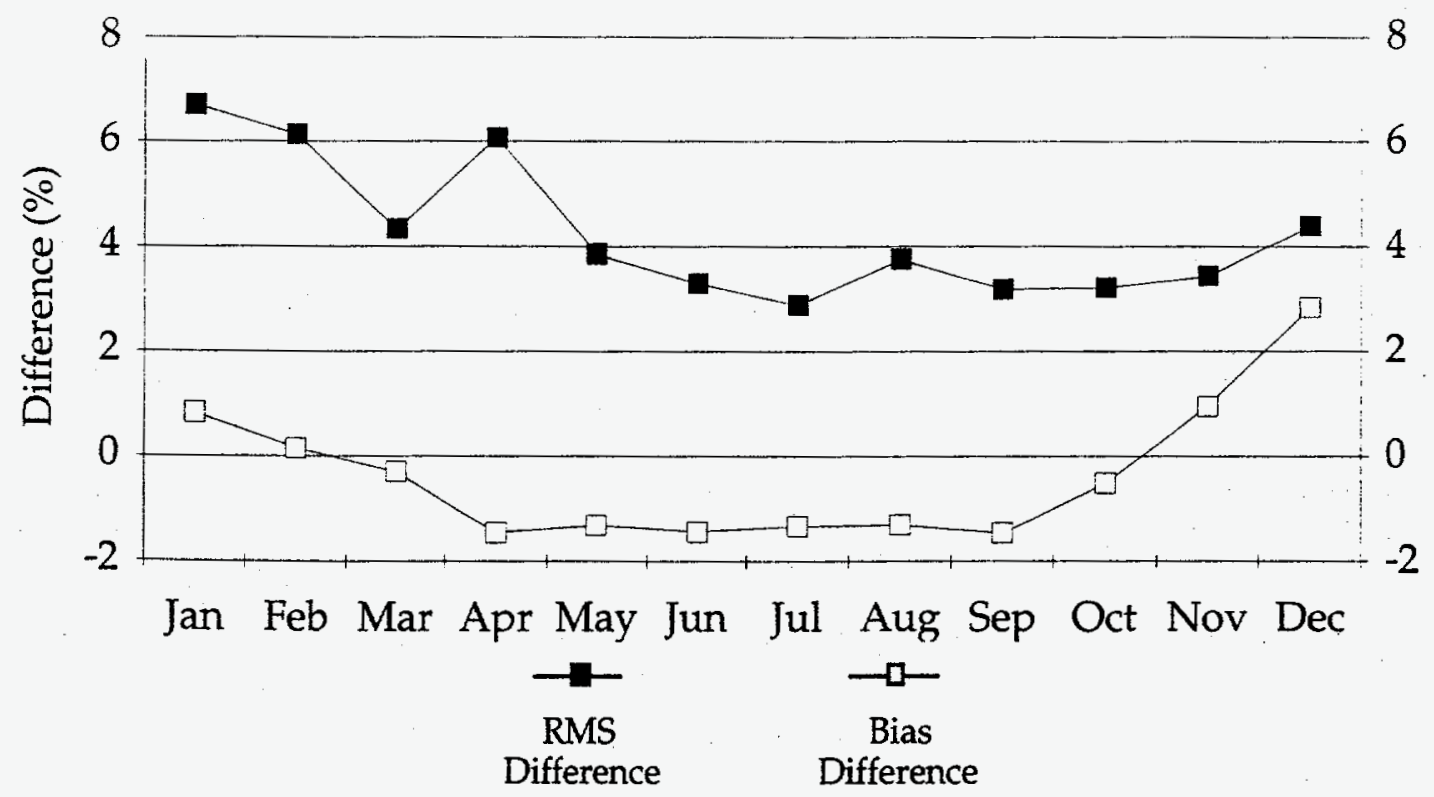

Figure 3-2. Global Horizontal Insolation RMS and Bias Differences 
For the 12-month period, yearly global horizontal insolation values of 1906.4 and 1920.2 $\mathrm{kWh} / \mathrm{m}^{2}$ were recorded by the RSR LI-COR and the calculated reference, respectively, an overall difference of $-0.7 \%$ for the year.

Monthly average RMS differences in excess of $6 \%$ were observed for the 10 -minute LICOR horizontal irradiance readings. At the same time, the average monthly bias for these readings was generally less than half of this value. This indicates that the LI-COR measurements both overestimated and underestimated the global irradiance throughout the month. The result was relatively large inaccuracies in the instantaneous and short-term readings (6\%) but much smaller inaccuracies in the monthly sums ( $2 \%$ ). The conditions that cause the LI-COR to over and underestimate the global irradiance are described in the Analysis section of this report (Section 4.1).

\subsection{Diffuse Horizontal Insolation}

Figure 3-3 presents monthly sums of the diffuse horizontal insolation recorded by the RSR and the reference PSP/SBS (corrected). Figure 3-3 also shows the percentage differences between the monthly sums. For the 12-month period, yearly diffuse horizontal insolation values of 508.6 and $548.9 \mathrm{kWh} / \mathrm{m}^{2}$ were recorded by the RSR and the reference radiometer, respectively. This represents an overall yearly difference of $-7.2 \%$.

Unlike the global irradiance, the diffuse irradiance generally had a large, negative monthly average bias (up to $-15 \%$ ), and this bias was the major constituent of the total, RMS difference. As a result, the RSR consistently underestimated the diffuse radiation. Some of the factors that cause this effect are explained below (Section 4.1). 


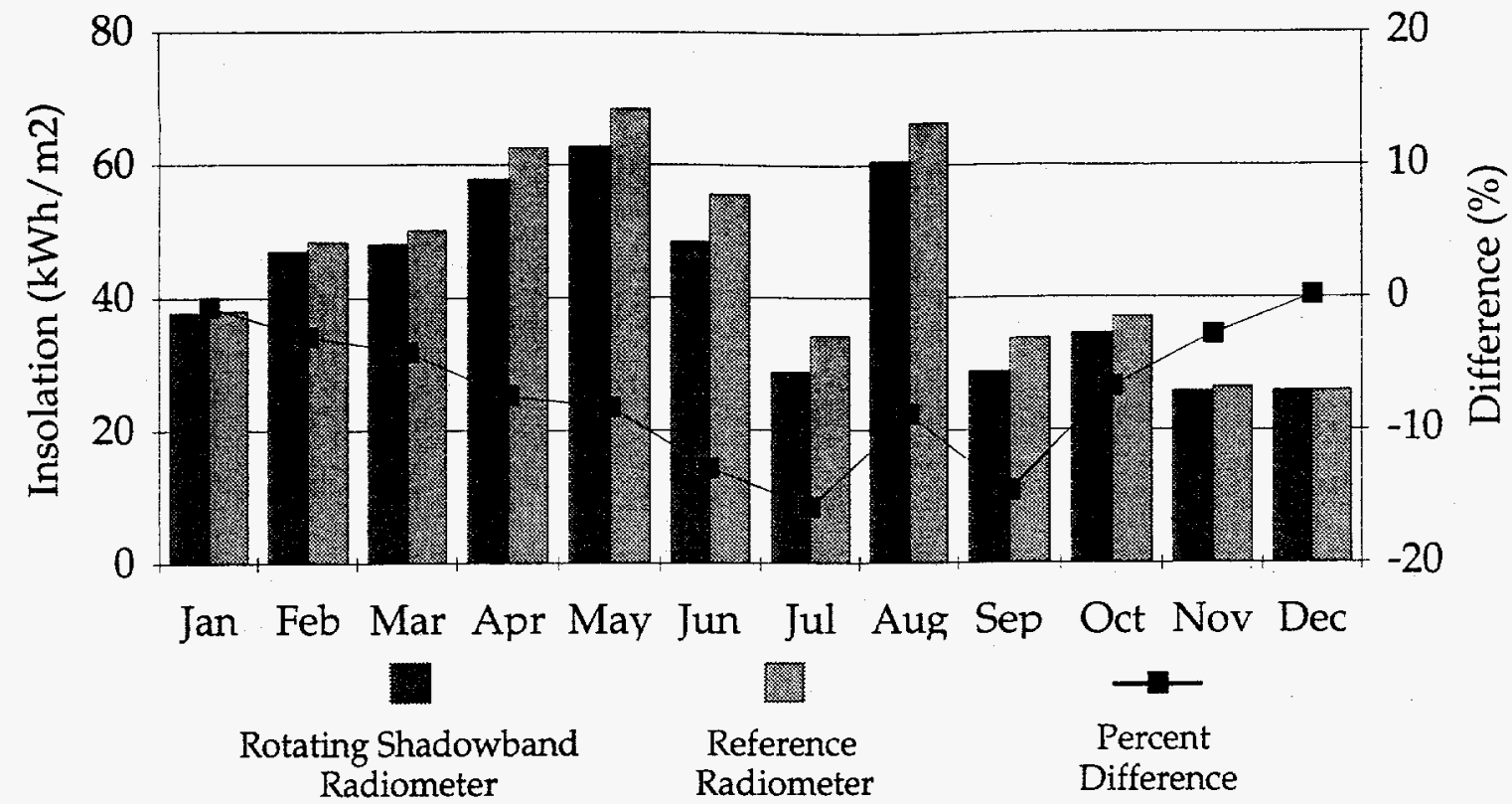

Figure 3-3. Monthly Diffuse Horizontal Insolation Sums and Differences

Figure 3-4 shows the RMS and bias differences observed between the RSR and reference data. These differences are calculated for each 10-minute data pair and averaged over each month.

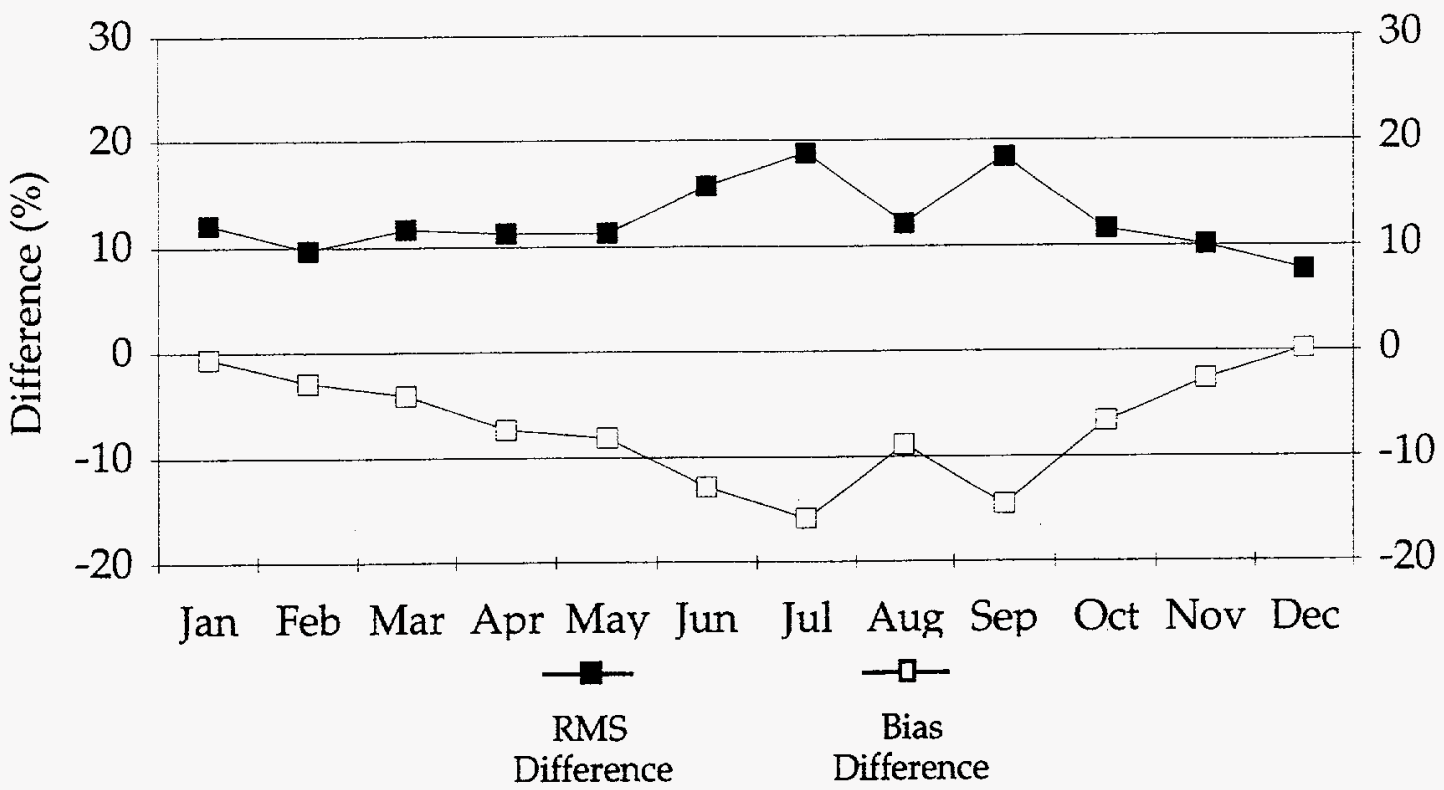

Figure 3-4. Diffuse Horizontal Insolation RMS and Bias Differences 


\subsection{Direct Normal Insolation}

Figure 3-5 presents monthly sums of the direct normal insolation recorded by the RSR and the NIP. Also shown in Figure 3-5 are the percentage differences between these monthly sums. For the 12-month period, yearly direct normal insolation values of 2353.1 and $2277.5 \mathrm{kWh} / \mathrm{m}^{2}$ were recorded by the RSR and the reference radiometer, respectively. This represents an overall difference of $3.3 \%$ in the yearly total.

As would be expected, the bias difference for the RSR direct normal irradiance is consistently positive. This is the result of the RSR's general underestimation of the diffuse component. Monthly average RMS differences in excess of $7 \%$ were recorded, though bias differences accounted for greater than half of these values. A data set with a known bias can be corrected to subtract the bias and yield more accurate results. This approach and two more complex methods of data remediation for the RSR direct normal irradiance are presented below in section 4.3.

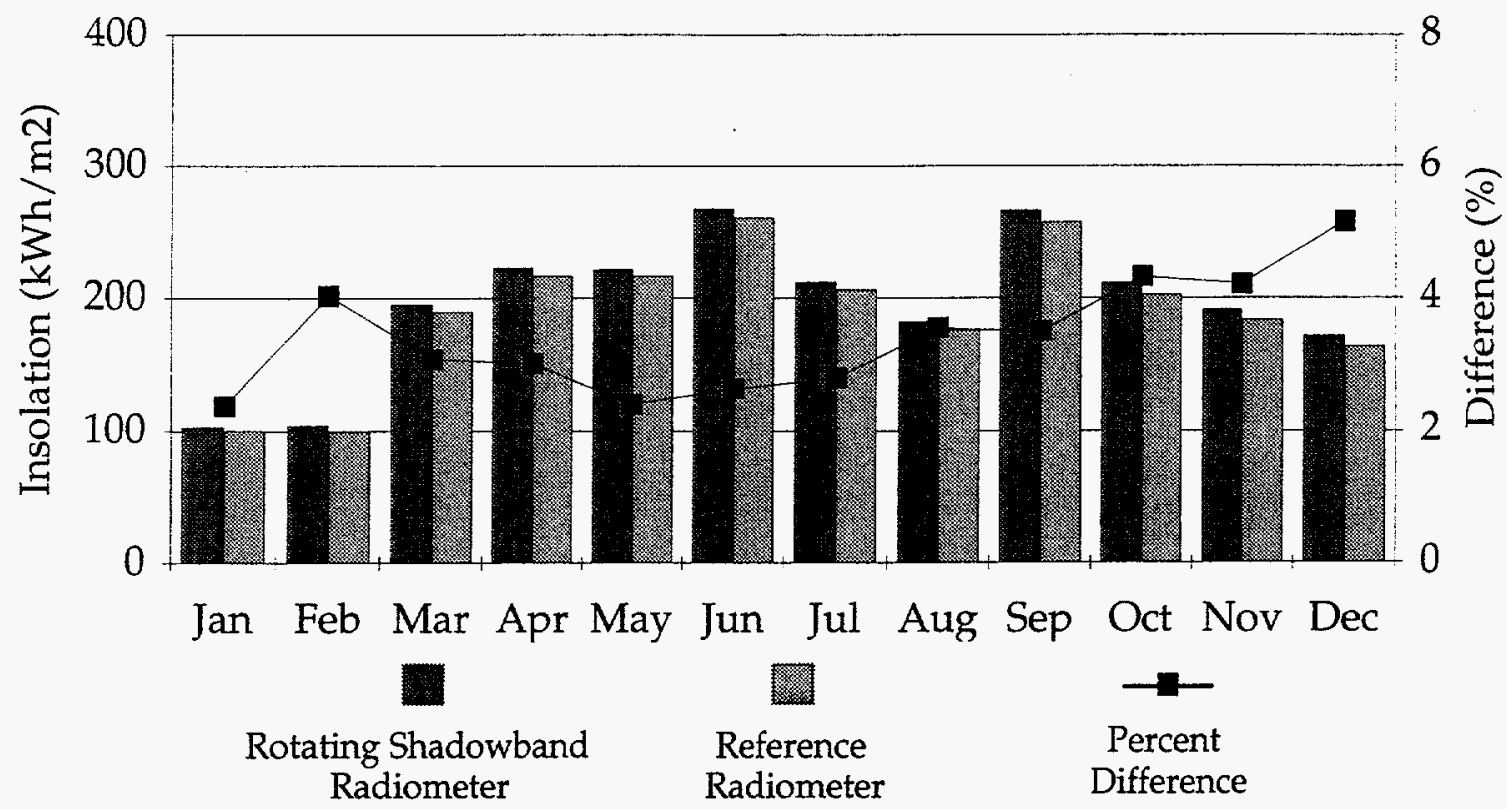

Figure 3-5. Monthly Direct Normal Insolation Sums and Differences

Figure 3-6 shows the RMS and bias differences between the RSR and reference data. These differences are calculated for each 10-minute data pair and averaged over each month. 


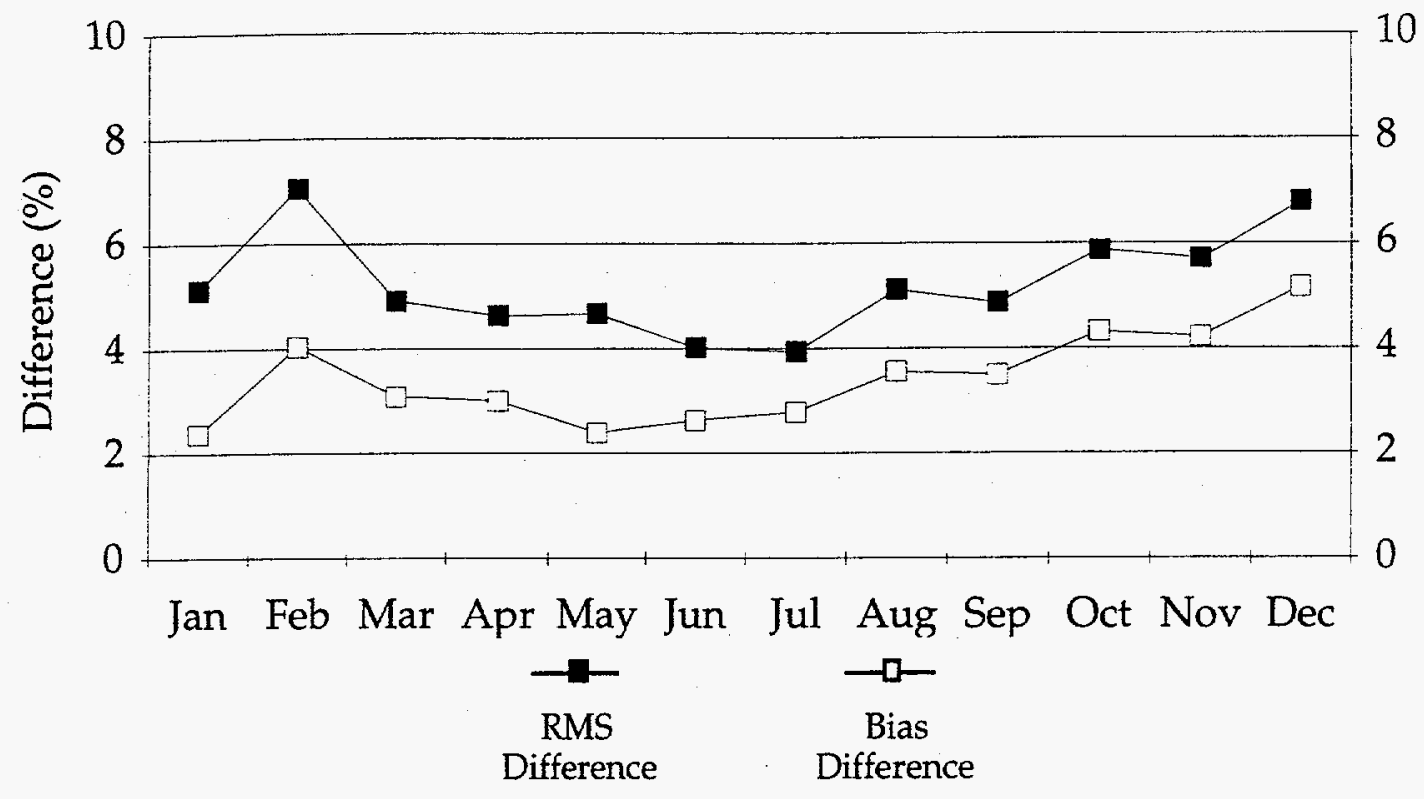

Figure 3-6. Direct Normal Insolation RMS and Bias Differences 


\subsection{ANALYSIS}

\subsection{Spectral Effects}

Thermopile radiometers transfer the radiant energy falling on a detector into heat energy and are generally considered spectrally nonselective. The silicon detector used by the RSR, conversely, converts radiant energy directly to electrical current and is highly spectrally selective. Figure 4-1 shows the response curve for the LI-COR silicon pyranometer (1) superimposed on typical clear sky direct, global, and diffuse spectra. The spectra were created using the SPCTRAL2 model developed by Bird and Riordan (9), with the following major parameters: Julian day $=90$; zenith angle $=48.3^{\circ}$; pressure $=1013 \mathrm{mb}$; turbidity at $500 \mathrm{~nm}=0.1$; water vapor $=1.4 \mathrm{~cm}$; ground albedo $=0.2$; and ozone $=0.344 \mathrm{~atm}-\mathrm{cm}$.

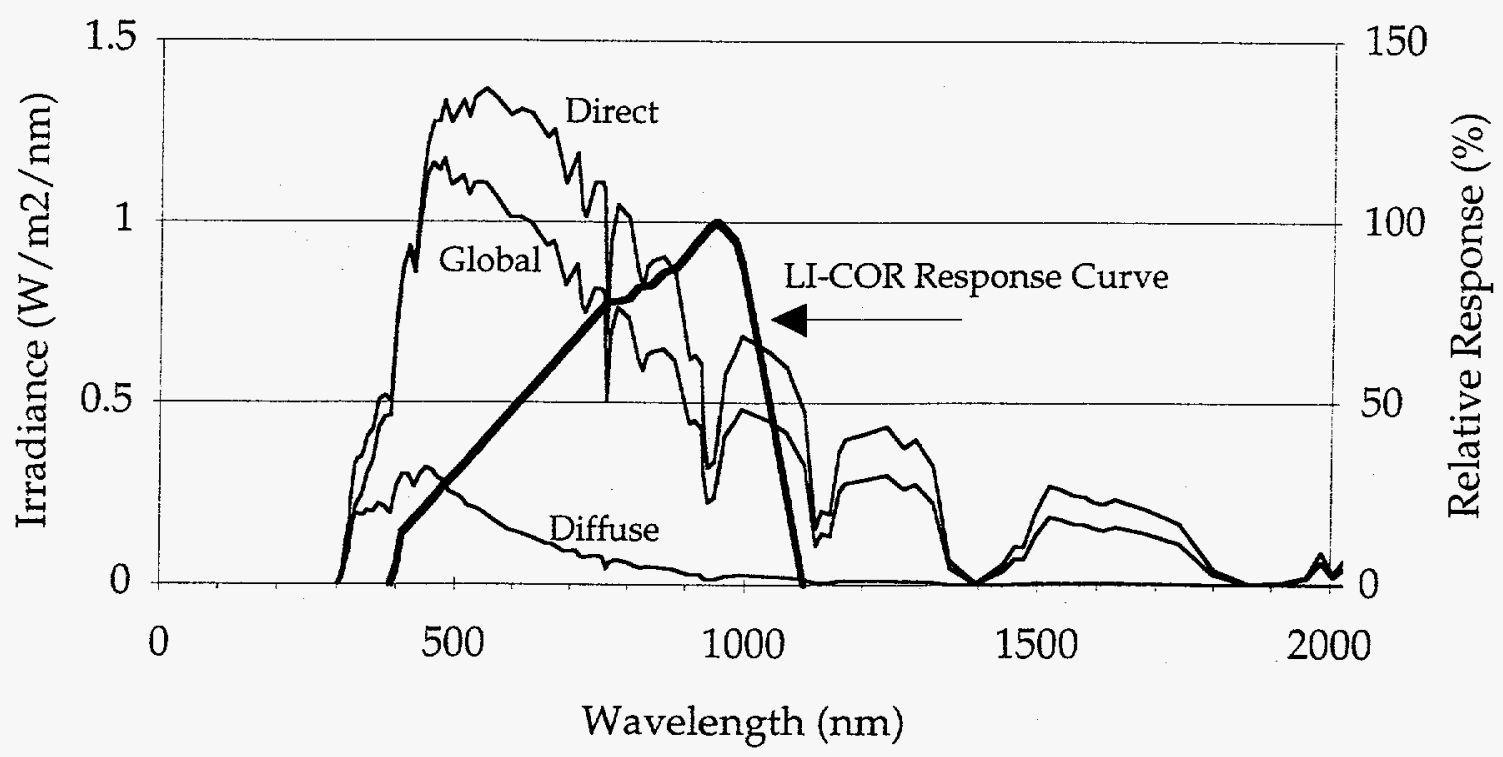

Figure 4-1. LI-COR Response Curve

As shown in Figure 4-1, the silicon detector provides no response to radiation in the near-UV (NUV, $300-380 \mathrm{~nm}$ ), has a linearly increasing response in the visible (VIS, 380 $-780 \mathrm{~nm}$ ), a sharp roll-off in response at $950 \mathrm{~nm}$ and then no response to the rest of the near-infrared (NIR, $780-4000 \mathrm{~nm}$ ) beyond $1100 \mathrm{~nm}$. The wavelength selective response curve of a pyranometer would not matter if the spectral content of sunlight remained constant. The spectral distribution of visible solar radiation reaching the ground is not 
constant but varies with air mass, cloud cover, turbidity, atmospheric water vapor content, and the reflective characteristics of the ground's surface (2). Considering global radiation, some general effects of these parameters are listed below in Table 4-1.

\section{Table 4-1. Parameters Influencing Global Spectral Distribution}

\begin{tabular}{ll} 
Parameter & \multicolumn{1}{c}{ Effect } \\
Air Mass & $\begin{array}{l}\text { Proportionately less transmittance of NUV and blue } \\
\text { wavelengths as air mass increases }(\underline{11}) \\
\text { Cloudy skies transmit proportionately more NUV and blue } \\
\text { wavelengths than do clear skies }(\underline{10})\end{array}$ \\
Turbidity & $\begin{array}{l}\text { Complex scattering and absorption relationships; spectral } \\
\text { effects are difficult to model accurately }(\underline{13})\end{array}$ \\
Water Vapor & $\begin{array}{l}\text { Sharp absorption peaks in selected wavelength bands (724, } \\
\text { 824, 938, and 1120 nm) }\end{array}$ \\
Albedo & $\begin{array}{l}\text { Multiple reflection between the ground and clouds can be } \\
\text { important for highly reflective surfaces; ground albedo is } \\
\text { highly site and season dependent }(10)\end{array}$
\end{tabular}

Solar spectral radiation that has been proportionately shifted toward the red and NIR, such as under conditions of high air mass, will be overestimated by the LI-COR pyranometer. Solar spectral radiation shifted toward the NUV and blue end of the spectrum, such as under partly-cloudy skies, is underestimated by the LI-COR.

The silicon pyranometer used in the RSR is calibrated against a PSP under natural sunlight over the course of several days (1). The calibration constant arrived at in this way provides a reasonable compromise of response to a variety of conditions under which the detector overestimates or underestimates the incident radiation. The efficacy of this calibration can be judged by comparing the monthly and yearly global horizontal insolation totals for the silicon pyranometer with those of the calculated global horizontal insolation: though individual (10-minute) RMS differences of 7-8\% were common, differences between monthly sums did not exceed $\pm 2 \%$ and a difference of less than $1 \%$ was observed between the yearly totals.

This cancellation of errors is not possible for measurements that demonstrate strong bias differences. This is the case for the diffuse measurements made by the RSR. Under mostly-clear skies, the diffuse component has a spectral distribution that is similar to, but slightly blue-shifted from, the global spectral irradiance (14). That is, the diffuse 
component contains proportionately more radiation in the wavelengths of weaker response for the silicon detector. As a result, the calibration constant appropriate for the calculation of global irradiance (in $\mathrm{W} / \mathrm{m}^{2}$ ) from silicon detector output (an electrical current), is inaccurate when used with a shaded pyranometer under clear sky conditions. Under cloudy conditions, the diffuse and global spectra agree more closely and the RSR inaccuracies are less. In summary, the RSR experiences the most inaccuracies in its determination of the diffuse component under clear sky conditions.

An illustration of the clear sky performance of the RSR is presented in Figure 4-2. This figure presents data collected on a typical clear day, 20 September 1993.

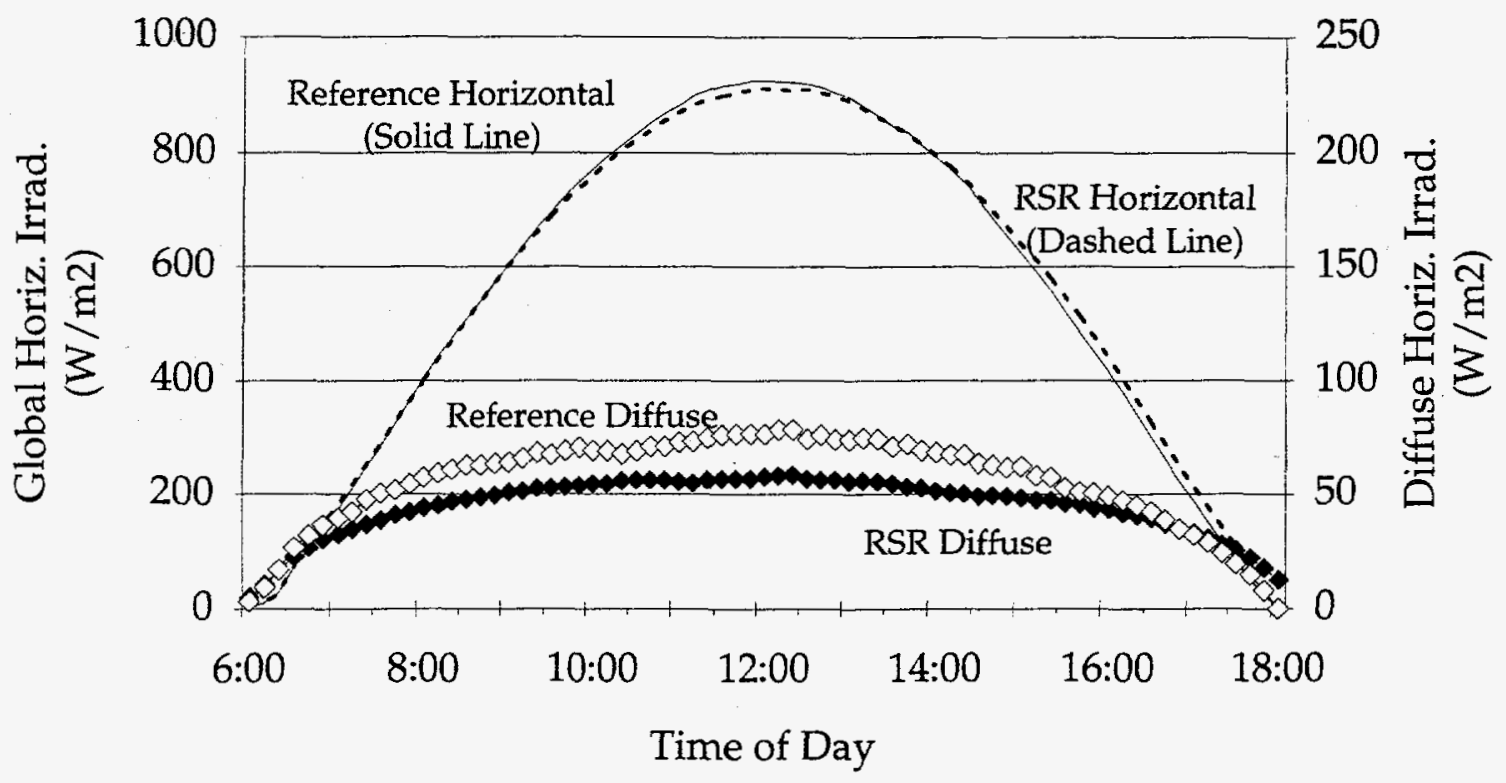

Figure 4-2. Clear Day Global and Diffuse Horizontal Irradiance: 20 September 1993

In this example, mid-day differences for the global horizontal irradiance readings were on the order of $1-2 \%$. At the same time, the mid-day differences for the diffuse horizontal measurements were approximately $20 \%$. As a result, at mid-day, the RSR overestimated the direct normal component under these clear sky conditions by several percent. 


\subsection{Temperature Effects}

The thermopile-based reference radiometers used in this study all incorporate compensation circuitry to overcome changes in instrument output with temperature. Eppley specifies a temperature dependence of $\pm 1 \%$ over normal operating conditions. The LI-COR silicon pyranometer contains no temperature compensation mechanism. The specification for the LI-200SZ pyranometer is given as $\pm 0.15 \%$ per ${ }^{\circ} \mathrm{C}$.

In practice, it is difficult to isolate the effects of temperature on pyranometer response from the coincident effects of changing air mass, cloud cover, etc. For the RSR under test, the temperature of the LI-COR is not recorded. However, a silicon-based UV pyranometer of similar design is monitored among the reference instruments. The temperature of this pyranometer is recorded and this temperature can be used as an approximation of the LI-COR detector's temperature. This has been done in Figure 4-3. Figure 4-3 presents data recorded during July 1993. Data acquired at solar zenith angles greater than $60^{\circ}$ have been excluded. The figure plots the ratio of the LI-COR global horizontal irradiance to the reference (calculated) global horizontal irradiance on the ordinate axis. The UV pyranometer temperature is plotted along the abscissa.

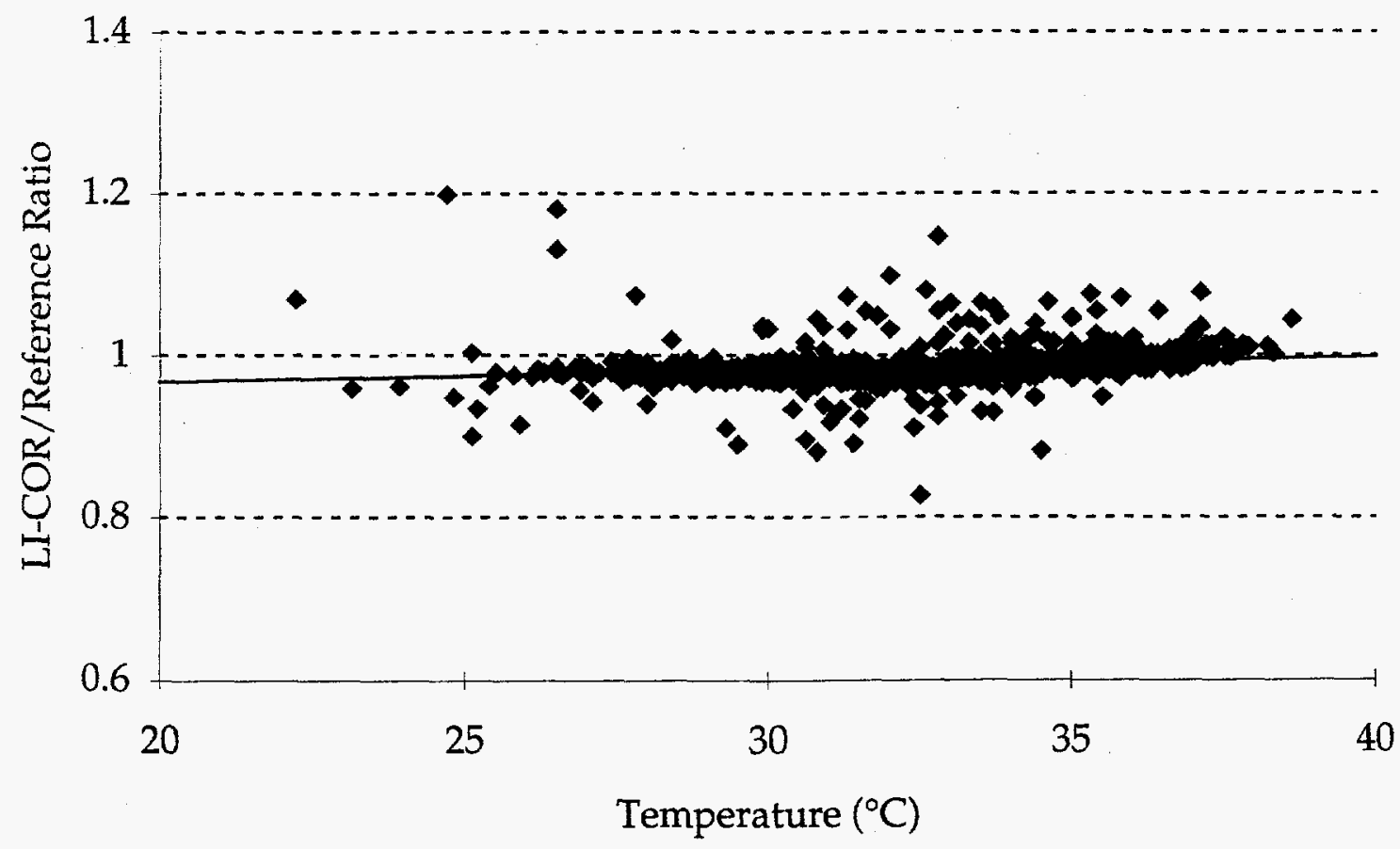

Figure 4-3. Effects of Temperature on LI-COR Response 
For this data set (with the necessary instrument temperature approximations), the LICOR temperature dependence was about $0.19 \%$ per ${ }^{\circ} \mathrm{C}$. The manufacturer does not specify an operating temperature range for this pyranometer. If we assume that in normal operation, the pyranometer will experience an operating temperature range of $\pm 20^{\circ} \mathrm{C}$ of the temperature at which it was calibrated, this can give rise to worst-case temperature induced inaccuracies of approximately $\pm 4 \%$.

\section{3 $\quad$ RSR Direct Normal Irradiance Data Remediation}

Obtaining accurate direct normal irradiance readings is the most important requirement for a radiometer used in performance assessment of concentrating solar thermal arrays. For this reason, three methods were examined to improve the accuracy of the RSR direct normal irradiance data.

The first method was a simple subtraction of the positive bias. This entailed multiplying each direct normal reading by 0.966 . As expected, this effectively reduced the average monthly bias difference, from $3.4 \%$ to near zero. This simple correction also reduced the average monthly RMS difference from $5.6 \%$ to $4.5 \%$, an improvement of $20 \%$.

It is not known if the average bias difference of 3.4\% observed at the NSTTF can be used to correct direct normal irradiance data recorded by other RSR instruments in other locations. It may be found that site specific conditions (e.g. the average daily cloud cover) make the average bias difference a site specific variable. In any case, it is likely that a review of the data from other sites operating a NIP and RSR side-by-side (at least two sites are known to the authors) can yield an 'average' RSR correction factor for general use.

The other two techniques used to improve data accuracy were more complex in nature. The first followed the method developed by Michalsky, et. al. (15). Using this procedure, one first corrects for effects of operating temperature on sensor (silicon) output. Actual readings are normalizing against sensor response measured at a standard temperature of $30^{\circ} \mathrm{C}$. Additional correction is then performed to compensate for spectral effects. Raw data are sorted into categories based on the solar zenith angle and two calculated parameters named sky clearness $(\varepsilon)$ and skylight brightness $(\Delta)$. A 
program that implements this correction procedure was supplied by ATI. However, since the RSR does not monitor the temperature of the silicon detector, the ATI program performs correction based on ambient rather than device temperature. This is a deviation from the technique described in the literature.

For the second correction technique, a limited attempt at derivation of a temperature independent correction algorithm was undertaken. Inspection of the data revealed that errors in the RSR direct normal irradiance readings increased non-linearly with zenith angle. The errors were generally small at small angles and showed a rapid increase at the extremes. When error magnitude was plotted, its shape closely followed the curve traced by the fourth power of the zenith angle. With a constant $(1 / 40)$ applied to scale the magnitude of the zenith angle correction, the following algorithm was derived and applied to RSR data :

$$
\mathrm{I}_{\mathrm{d}} \text { (corrected) }=\mathrm{I}_{\mathrm{d}} *\left(1-z^{4} / 40\right)
$$

where $I_{d}$ is the direct normal irradiance, and $z$ is the solar zenith angle in radians.

Table 4-2 summarizes the results of correcting the raw RSR direct normal irradiance data using the three techniques: a) a simple $3.4 \%$ bias subtraction; $b$ ) the ATI program (Michalsky (1991) less device temperature correction); and c) the temperature independent algorithm of equation 4.1.

Table 4-2. Direct Normal Irradiance Correction Algorithm Comparison

$\begin{array}{cc}\text { Mean Monthly } & \text { Median Monthly } \\ \text { RMS Difference (\%) } & \text { RMS Difference (\%) }\end{array}$

RSR Uncorrected

3.4\% Bias Subtraction

ATI/Michalsky Method

Temp. Independent (eq 4.1)
5.6

4.5

4.3

3.8
5.9

4.4

3.8

3.4
Mean Monthly

Bias Difference (\%)

The temperature independent correction (eq 4.1) yielded the best agreement to the reference radiometer readings. The mean RMS difference of $3.8 \%$ represents about 22 $\mathrm{W} / \mathrm{m}^{2}$. The negative bias in the ATI/Michalsky corrected data was expected given the use of ambient (cooler) rather than device (warmer) temperature to correct the raw 
readings. It is likely that the ATI/Michalsky technique can be changed to use a calculated approximation for device temperature that will increase the accuracy of the correction and yield results more in agreement with those of the original authors. 


\subsection{CONCLUSIONS}

A study of over one year's data from a rotating shadowband radiometer (RSR) has revealed some of the performance characteristics of this instrument. Based on this study, the following general conclusions are drawn:

- Reliability and availability of the ATI rotating shadowband radiometer were excellent. No operator intervention, repair, or realignment was required for normal use. Regular resetting of the instrument's internal clock (accomplished via modem) was required.

- The accuracy demonstrated by the RSR is adequate for many uses, such as general purpose solar resource assessment, when integration over long periods of time (weeks, months) is performed.

- Inaccuracies inherent in the use of an uncompensated silicon detector pyranometer render the instantaneous and short-duration readings of the RSR less accurate than is normally required for precise monitoring tasks such as are needed for performance assessment of concentrating solar collectors. However, post-collection correction algorithms improve the accuracy of the data and increase the instrument's suitability for these tasks. 


\section{REFERENCES}

1. LI-COR, inc. LI-COR Radiation Sensors Instruction Manual, 14 (1986).

2. Kinsell L. Coulson. Solar and Terrestrial Radiation, 94 (1975).

3. Edward C. Kern, Jr. and Miles C. Russell. Rotating Shadow Band Pyranometer Irradiance Monitoring for Photovoltaic Generation Estimation. The Conference Record of the Twenty Second IEEE Photovoltaic Specialists Conference -- 1991, 541 (1991).

4. J. J. Michalsky, R. Perez, R. Stewart, B. A. LeBaron and L. Harrison. Design and Development of a Rotating Shadowband Radiometer Solar Radiation/Daylight Network. Solar Energy 41, 577 (1988).

5. D. R. Myers, K. A. Emery and T. L. Stoffel. Uncertainty Estimates for Global Solar Irradiance Measurements Used To Evaluate PV Device Performance. Solar Cells 27, 455 (1989).

6. J. A. Duffie and W. A. Beckman. Solar Engineering of Thermal Processes, 55 (1980).

7. Thomas Stoffel, Carol Riordan and John Bigger. Joint EPRI/SERI Project to Evaluate Solar Radiation Measurement Systems for Electric Utility Solar Radiation Resource Assessment. The Conference Record of the Twenty Second IEEE Photovoltaic Specialists Conference -- 1991, 533 (1991).

8. Richard Bird. Spectral Terrestrial Solar Radiation. Solar Resources (Hulstrom ed.), 309 (1989).

9. Richard E. Bird and Carol Riordan. Simple Solar Spectral Model for Direct and Diffuse Irradiance on Horizontal and Tilted Planes at the Earth's Surface for Cloudless Atmospheres. Journal of Climate and Applied Meteorology 25, 87 (1986).

10. Stefan Nann and Carol Riordan. Solar Spectral Irradiance under Clear and Cloudy Skies: Measurements and a Semiempirical Model. Journal of Climate and Applied Meteorology 30, 447 (1991).

11. Richard E. Bird. A Simple, Solar Spectral Model for Direct-Normal and Diffuse Horizontal Irradiance. Solar Energy 32, 461 (1984). 
12. Bo Leckner. The Spectral Distribution of Solar Radiation at the Earth's Surface-Elements of a Model. Solar Energy 20, 143 (1978).

13. E. C. Flowers, R. A. McCormick and K. R. Kurfis. Atmospheric Turbidity over the United States, 1961-1966. Journal of Applied Meteorology 8, 955 (1969).

14. K. W. Boer. The Solar Spectrum at Typical Clear Weather Days. Solar Energy 19, 525 (1977).

15. J. J. Michalsky, R. Perez, R. Stewart, L. Harrison and B. A. LeBaron. Spectral and Temperature Correction of Silicon Photovoltaic Solar Radiation Detectors. Solar Energy 47, 299 (1991). 
Advanced Thermal Systems

Dave Gorman

7600 East Arapahoe Rd. Suite 215

Englewood CO 80112

\section{Alabama Solar Energy Center \\ Leonard Adcock \\ University of Alabama in Huntsville \\ Huntsville AL 35899}

American Energy Technologies, Inc.

Steven K. Gorman

3530 Enterprise Way

Green Cove Springs FL 32043-1865

Michelle Appenzeller

5218 C. R. 218

Middleburg FL 32068

Applied Concepts

S. Pond

2501 S. Larimer County Rd. 21

Berthound CO 80513

Argonne National Laboratory

Materials and Components Technology Div.

Robert E. Holtz

9700 South Cass Avenue

Argonne IL 60439

Arizona Department of Commerce

Arizona Energy Office

Frank P. Mancini, Ph.D.

3800 N. Central, Suite 1200

Phoenix AZ 85012

Arizona Public Service Company

Peter E. Eckert

1500 E. University

Tempe AZ 85281

Arizona State University

College of Engineering and Applied Sciences

Byard D. Wood, Ph.D., P.E.

Director and Professor

Tempe, AZ 87287-5806

Ascension Technology

Ed Kern

Box 314

Lincoln Center MA 01773

Augustyn \& Company

Jim Augustyn

1029 Solano Ave., Suite C

Albany CA 94706
Babcock \& Wilcox

Pat Bator

$20 \mathrm{~S}$. Van Buren Ave.

Barberton OH 44203

Barber-Nichols Engineering

R. Barber

6325 West 55th Ave

Arvada CO 80002

Battelle Memorial Institute

Pacific Northwest Laboratory

K. Drumheller

$4000 \mathrm{NE} 41$ st St.

Seattle WA 98105

Bechtel Group, Inc.

P. DeLaquil

PO Box 3965

50 Beale Street

San Francisco CA 94119

Bechtel Group, Inc.

W. Stolte

PO Box 3965

50 Beale Street

San Francisco CA 94119

Beckwith Electric Company

R. W. Beckwith

PO Box 2999

Largo FL 34649-2999

Boeing Engineering \& Construction

R. Gillette

PO Box 3999

Seattle WA 98124

Brookhaven National Labs

John Andrews

National Center for Analysis of Energy Systems

Upton NY 11973

Cal Poly State University

E. J. Carnegie

San Luis Obispo CA 93407

California Polytechnic University

Dept. of Mechanical Engineering

W. B. Stine

Pomona CA 91768-4062

Colorado State University

Dr. Allan T. Kirkpatrick

Department of Mechanical Engineering

Fort Collins CO 80523 
Colorado State University

T. G. Lenz

Ft. Collins CO 80523

Conserval Systems Inc.

John C. Hollick, P.E.

2211 Main St., Bldg B

Buffalo NY 14214

County of Hawaii

Steve Burns

Dept. of Research and Development

25 Aupuni Street

Hilo HI 96720

Cummins Engine Company

Dr. Isoroku Kubo

Mail Code 50160

Box 3005

Columbus IN 47202-3005

D\&T Solar

Thomas Caldwell

418 Vista Larga

Los Lunas NM 87031

Duke University

T. C. Wilson

Dept. of Elec. Engr.

Durham NC 27706

DynCorp Meridian

Robert E. N. Muhn

Technical Director, International Projects

4300 King Street, Suite 400

Alexandria, VA 22302-1508

Electric Power Research Inst.

J. Bigger

3412 Hillview Avenue

Palo Alto CA 94303

Electric Power Research Inst.

E. DeMeo

3412 Hillview Avenue

Palo Alto CA 94303

Energy Concepts Co.

Don Erickson

627 Ridgely Ave.

Annapolis MD 21401

ENTECH, Inc.

M. O'Neill

PO Box 612246

DFW Airport TX 75261
Environmental Laboratory

John A. Dufay

915 Locust St. SE

Albuquerque NM 87106-4300

Environmental Technology \&

Education Center (ETEC)

Jon Nimitz, Ph.D.

3300 Mountain Road NE

Albuquerque, NM 87106-1920

ESELCO

Sheldon L. Levy

8116 Fontana

Prairie Village KS 66208

FAFCO

Freeman Ford

2690 Middlefield Road

Redwood City CA 94063

Federal Conservation \& Renewable Energy Referral Service

PO Box 8900

Silver Spring MD 20907

Federal Energy Management Activities

CE 10.1

U.S. Department of Energy

1000 Independence Ave.

Washington DC 20585

Florida Solar Energy Center

David Block

300 State Road 401

Cape Canaveral FL 32920

Florida Solar Energy Center

Kirk Collier

300 State Road 401

Cape Canaveral FL 32920

Florida Solar Energy Center

John Harrison

300 State Road 401

Cape Canaveral FL 32920

Florida Solar Energy Center

Jim Huggins

300 State Road 401

Cape Canaveral FL 32920

Foster Wheeler Solar Dev. Corp.

M. D. Garber

12 Peach Tree Hill Road

Livingston NJ 07039 
Harris Corporation

Byron F. Knight

Manager-Advanced Programs

PO Box 91000

Melbourne FL 32902-9100

Hilda Frazier DCA

2740 Centerview Drive

Tallahassee FL 32399-2100

Garrett Turbine Engine Co.

Ed Strain

111 South 34th Street

PO Box 5217

Phoenix AZ 85010

Hawai'i Energy Extension Service

Andrea Beck

Department of Business, Economic Development and

Tourism

99 Aupuni Street \#214

Hilo HI 96720

Hawaii Solar Energy Association

Ron Richmond

PO Box 23350

Honolulu Hawaii 96823

Heliodyne, Inc.

Jurg H. Bieri, Ph.D.

4910 Seaport Ave.

Richmond CA 94804

Heliotrope

Malcolm Herbert

3733 Kenora Drive

Spring Valley CA 92077

Heliotrope

Dave Parks

3733 Kenora Drive

Spring Valley CA 92077

Industrial Solar Technology

Randy Gee

5771 West 52nd Ave.

Denver CO 80212

Institute of Gas Technology

Library

34245 State Street

Chicago IL 60616

International Planning Assoc, Inc

Editor

807 Caddington Ave.

Silver Spring MD 20901
Intersol Power Corporation

John Sanders

8590 S. Mariposa Dr.

Morrison CO 80465-2424

Kenneth S. Jurman

Institutional Conservation Program

9th Street Office Building/8th Floor

202 North Ninth Street

Richmond VA 23219

Kearney \& Associates

David W. Kearney

14022 Condessa Drive

Del Mar CA 92014

KJC Operating Company

Gilbert Cohen

41100 Highway 395

Boron CA 93516

Carlo LaPorta

650381 st St

Cabin John, MD 20818-1204

Lawrence Berkeley Laboratory

Dr. Arlon Hunt

Building 90-2024

University of California

Cyclotron Road

Berkeley CA 94720

Ted Lewis \& Associates

Edward G. Lewis

556 East Gill Way

Superior CO 80027

Pennsylvania State University

Dr. Russell Messier

Material Research Laboratory

University Park PA 16802

Michigan State University

Jerry Park

Elec. Engr. Dept.

Engr. Bldg., Rm. 260

East Lansing MI 48824 .

Midway Labs

Paul Collard

2255 East 75th Street

Chicago IL 60649

Midwest Research Institute

R. L. Martin

425 Volker Blvd.

Kansas City MO 64110 
Minnesota Power Co.

John Kappenman

30 West Superior Street

Duluth MN 55802

MIT

J. G. Kassalkian

Elec. Power Systems Engr. Lab

Cambridge MA 02139

MIT

M. F. Schlecht

Elec. Power Systems Engr. Lab

Cambridge MA 02139

Montana State University

R. Johnson

Dept. of Elec. Engr.

Bozeman MT 59717

National Renewable Energy Lab

Russ Hewett

1617 Cole Blvd.

Golden CO 80401-3393

National Renewable Energy Lab

Jim Jones

1617 Cole Blvd.

Golden CO 80401-3393

National Renewable Energy Lab

Mary Jane Hale

1617 Cole Blyd.

Golden CO 80401-3393

National Renewable Energy Lab

Tom Williams

1617 Cole Blvd.

Golden CO 80401-3393

National Renewable Energy Lab

Meir Carasso, Ph.D., P.E.

Manager, Thermal Science Research Section

1617 Cole Blvd.

Golden CO 80401-3393

National Renewable Energy Lab

Roger W. Taylor

Project Manager

1617 Cole Blvd.

Golden CO 80401-3393
New Mexico Institute of

Mining \& Technology

Joe Galon

Associate Director of Engineering

Physical Plant Department

Campus Station

Socorro NM 87801

New Mexico R\&D Forum

University of New Mexico

Richard Cole

Director

R\&D Communication Office

Albuquerque NM 87131-6076

National Tech Transfer Center

Wheeling Jesuit College

316 Washington Ave.

Wheeling WV 26003

Pacific Gas and Electric Company

Joseph J. Iannucci

Program Manager

3400 Crow Canyon Road

San Ramon CA 94583

Packerland Solar System

Richard Lane

PO Box 8262

Green Bay WI 54308

PAL Engineering Services, Inc.

Ken Lambert, VP

U.S. Office: 621 Heather Knoll

Desoto TX 75115

Parsons of California

D. R. Biddle

PO Box 6189

Stockton CA 95206

Pennsylvania Energy Office

Director

116 Pine Street

Harrisburg PA 17101-1227

Portland State University

Jean P. Murray, Ph.D.

PO Box 751

Portland OR 97207-0751

Power Kinetics, Inc.

W. E. Rogers

415 River Street

Troy NY 12180-2822 
Purdue University

Oleg Wasynczuk

School of Elec. Engr.

West Lafayette IN 47907

Radco Products, Inc.

George O. Radford

President

2877 Industrial Parkway

Santa Maria CA 93455

Renewable Energy Training Institute

Jeffrey S. Ross

Assistant Director

122 C Street, NW

Suite 520

Washington DC 20001

Rensselaer Polytechnic Inst.

Jose M. Borrego

EESE Dept. JEC 7020

Troy NY 12181

Research Triangle Institute

Carl Parker

PO Box 12194

Research Triangle Park NC 27709

Roan Corporation

James L. Abolt

177 Bovet Road, Suite 520

San Mateo CA 94402

Rockwell International Corporation

Energy Technology Engineering Center

Robert K. Hoside, C.E.M.

PO Box 1449

Canoga Park CA 91304

The Rovac Corp.

Raymond E. Shea, Sr.

President

PO Box 111

1030 Stafford St.

Rockdale MA 01542

SAIC

Barry L. Butler, SEIA Chairman

Room 2043, M/S C2J

10260 Campus Point Drive

San Diego CA 92121

San Jose State University

Helmer Nielsen

Dept. of Mech. Engr.

Washington Square

San Jose CA 95192
Scholfield Solar

Allen Carrozza

2450 Channel Drive, Suite A

Ventura CA 93003

Science Applications International Corp.

Kelly Beninga

Division 448

15000 West 6 th Ave., Suite 202

Golden CO 80401

Scientific Analysis, Inc.

John Allen Gunn, PE

6012 E. Shirley Lane

Montgomery AL 36117

SLEMCO

A. J. Slemmons

19655 Redberry Dr.

Los Gatos CA 95030

Sea Sun Power Systems

George Hagerman

124 East Rosemont Ave.

Alexandria VA 22301-2326

Segal's Solar Systems

Barry Jay Segal

3357 Cranberry South

Laurel MD 20724-2419

Sierra Club Rio Grande Chapter

Ken Hughes

Energy Chair

1204 Placita Loma

Santa Fe NM 87501

SMUD

Don Osborne

Box 15830

Sacramento CA $95852-1830$

Solar Energy Corporation

Robert Aresty

Box 3065

Princeton NJ 08540

Solar Energy Industries Assn

Linda Ladas

Suite 805

777 N. Capitol St. NE

Washington DC 20002-4226 
Solar Energy Industries Assn

Scott Sklar

Suite 805

777 N. Capitol St. NE

Washington DC 20002-4226

Solar Kinetics, Inc.

Gus Hutchison

10635 King William Drive

Dallas TX 75220

Solar Power Engineering Co. Inc.

T. Buna

PO Box 91

Mortison CO 80468

Solar Steam

D. E. Wood

PO Box 32

Fox Island WA 98333

State of California

California Energy Commission

Energy Technology Development Division

Research and Development Office

Promod Kulkarni

1516 9th Street

MS-43

Sacramento CA 95814-5512

State of Colorado

Office of Energy Conservation

Howard "Andy" Walker Ph.D., M.E.

Renewable Energies Coordinator

1675 Broadway

Suite 1300

Denver CO 80202-4613

State of Hawaii

David A. Rezachek, Ph.D., P.E.

Department of Business and Economic Development

335 Merchant St., Room 110

Honolulu HI 96813

State University of New York

Atmospheric Sciences Research Center

R. Perey

Albany NY 12222

Suntec Systems, Inc.

J. H. Davison

Suite B-4

Loring Park Office Bldg.

430 Oak Grove St.

Minneapolis MN 55403
Sustainable Energy Systems

David N. Borton, Ph.D., President

Hilltop Road

Troy NY 12180

The Solar Letter

Allan L. Frank

9124 Bradford Rd.

Silver Spring MD 20901-4918

Texas Tech University

Dept. of Electrical Engineering

E. A. O'Hair

PO Box 4439

Lubbock TX 79409

Thermacore, Inc.

Mr. Donald Ernst

780 Eden Road

Lancaster PA 17601

United States Environmental Protection Agency

Patricia C. Plympton

Special Assistant, Policy and Resources Development

Office of Administration

Safety, Health, and Environmental Management

Division

401 M Street SW (PM-273)

Washington, DC 20460

University of Central Florida

Dr. Gerard G. Ventre

Research Scientist

Institute for Simulation and Training

12424 Research Parkway

Suite 300

Orlando FL 32826

University of Colorado, Boulder

Dr. Jan F. Kreider, P.E.

Dept. of Civil Environmental and Architectural

Engineering

Boulder CO 80309

U.S. Army Corps of Engineers

Larry D. Lister

Mechanical Engineer

PO Box 4005

Champaign IL 61820-1305

3M-Solar Optics Program

Paul Jaster

$3 \mathrm{M}$ Center

Bldg. 225-2n-06

St. Paul MN 55144-1000 
3M-Solar Optics Program

Heather Kutzler

3M Center

Bldg. 225-2n-06

St. Paul MN 55144-1000

U.S. Department of Energy

Frank (Tex) Wilkins

1000 Independence Ave., SW

Washington DC 20585

U.S. Department of Energy

C. Carwile

1000 Independence Ave., SW

Washington DC 20585

University of Arizona

George V. Mignon

Environmental Research Lab.

Tucson AZ 85706-6985

University of Hawaii

Patrick Takahashi

Hawaii Natural Energy Inst.

2540 Dole Street

Honolulu HI 96822

University of Houston Energy Laboratory; SPA

Lorin Vant-Hull

Houston TX 77004

University of Lowell

Thomas Costello

1 University Avenue

Lowell MA 01854

University of Lowell

Fahd Wakim

1 University Avenue

Lowell MA 01854

University of Minnesota

E. A. Fletcher

Dept. of Mechanical Engineering

1111 Church St. SE

Minneapolis MN 55455

University of New Mexico

M. W. Wildin

Department of Mechanical Engr.

Albuquerque NM 87131

University of Texas at Arlington

Jack Fitzer

West 6th at Speer Street

Arlington TX 76019
University of Wisconsin

T. A. Lipo

Dept. of Elec. Engr. and Computer Science

Madison WI 52706

Virginia Polytechnic Institute and State University

Saifur Rahman, Ph.D.

Associate Professor

Electrical Engineering Department

Blacksburg VA 24061

Ross R. Wagner

744 E. Samaria

Eric MI 48133

Westinghouse Science \& Tech. Ctr.

Walter J. Dollard

Technology Director, Energy \& Utility Systems Group 1310 Buelah Rd.

Pittsburgh PA 15235

Wichita State University

Center for Energy Studies

Dr. Ward Jewell

Box 44

Wichita KS 67208

WG Associates

Vern Goldberg

6607 Stonebrook Circle

Dallas TX 75240

Wyle Laboratories

Don McAvin

7800 Governors Drive West

Huntsville AL 35807

Yankee Environmental Systems, Inc.

Mark C. Beaubien

Senior Engineer

101 Industrial Road

PO Box 746

Turners Falls, MA 01376

William E. Young

380 Milford Point Drive

Merritt Island FL 32952

Zomeworks

1011 A Sawmill Rd NW

Albuquerque NM 87104 


\section{FOREIGN}

Australian National University

Department of Engineering Physics

Prof. Stephen Kaneff

PO Box 4

Canberra ACT 2600

AUSTRALIA

Ministry of Energy

Ian Lewis

56 Wellesley Street West

Toronto, Ontario M7A 2B7

CANADA

Queens University

P. C. San

Dept. of Elec. Engr.

Kingston, Ontario

CANADA K7L 3N6

Railex Power \& Energy Group (IPP)

PO Box 2148

Vancouver, B.C.

CANADA V6B 3T8

Republic Equities Corporation

Mr. L. P. Bradley

PO Box 2874

Vancouver, B.C.

CANADA V6B3X4

University of British Columbia

W. G. Dunford

Dept. of Elec. Engr.

Vancouver, BC

CANADA V6T 1WS

University du Quebec

Trois-Rivieres

V. Rajegopalan

Dept. d'Ingehierie - C.P. 500

Trois-Rivieres, Quebec

CANADA G9A 5H7

University of Toronto

S. B. Dewan

Dept of Elec. Engr.

Toronto, Ontario

CANADA M5S 1A4

Solar Uno

Ellis Perez,

Vice-Presidente de Mercadeo y Ventas

Ave. Sarasota No. 54, Apto. 102

Santo Domingo, DOMINICAN REPUBLIC
Energy and Technology Associates

Attn: Dr. Adel Solimon

P.O.B. 39 El-Souk El-Togary

Maadi 11693

Cairo, EGYPT

DLR

Institute for Technical Thermodynamics

R. Buck

Pfaffenwaldring 38-40

7000 Stuttgart 80

FEDERAL REPUBLIC OF GERMANY

Energy Research Centre (2)

Attn: K. Inall

R.S. Phy. Sc.

Australian National University

Canberra ACT 2601

AUSTRALIA

Luz Industries Israel

Yoel Gilon

PO Box 7929

Jerusalem 91079

ISRAEL

PCJ Engineering, Ltd.

W.R. (Roddy) Ashby

Manager

Box 579

Kingston 10, JAMAICA

Thermosol Equipments

AH-158

Anna Nagar

Madras-600 040

\section{CONDUMEX}

Ing. Enrique Hill B.

So juana ines de la Cruz

34402o. Piso Tiainepantia. Edo. de Mexico

C.P. 54000

MEXICO

Diseno Solar y Arquitecturạ Bioclimatica

Dr. Everardo Hernandez

A-P 69-738

MEXICO, D.F. C.P. 04460

Ing. Armando Nava Escobedo

Jefe de Servicios de Conservacion

Durango 291-80 PISO

Colonia Roma

06700 MEXICO, D.F. 
Instalaciones Tecnicas Especializadas, S.A.

Attn: Ing. Enrique Ramoneda Carrillo

Gerente General

Bahia De Chachalacas 42

Mexico City, D.F. MEXICO 11300

Instituto de Investigaciones Electricas

Dr. Jorge M. Huacuz Villamar

Interior Internado Palmira

Apartado Postal 475

62000 Cuernavaca, Mor., MEXICO

Saudi Arabian National Center

for Science and Technology

Abbas A. Salim

PO Box 15164, Riyadh 11444

SAUDI ARABIA

Berna/Bernex AG

R. S. Bonetti/M. Tobler

Industriestrasse 36

$\mathrm{CH}-4600$

Olten, SWITZERLAND

National Rural Electric Cooperative Association

Pete Smith

Manager

5a. Avenida 16-28, Zona 10, 01010

Guatemala, Guatemala, C.A.

\section{INTERNAL DISTRIBUTION}

$\begin{array}{lll}1380 & \text { J. Hanks } & 4200 \\ 0702 & \text { A. Van Arsdall } & 6200 \\ 0753 & \text { G.J. Jones } & 6202 \\ 0752 & \text { T.C. Bickel } & 6213 \\ 1127 & \text { M.E. Ralph } & 6215 \\ 1127 & \text { R.A. Mahoney } & 6215 \\ 1127 & \text { M.E. Ralph } & 6215 \\ 1127 & \text { E.E. Rush } & 6215 \\ 1127 & \text { J.W. Strachan } & 6215 \\ 0703 & \text { C.E. Tyner } & 6216 \\ 0703 & \text { J.R. Anderson } & 6216 \\ 0703 & \text { C.W. Bennett } & 6215 \\ 0703 & \text { L.R. Evans } & 6216 \\ 0703 & \text { T.R. Mancini } & 6216 \\ 0703 & \text { D.F. Menicucci (5) } & 6216 \\ 0753 & \text { C.P. Cameron } & 6218 \\ 0753 & \text { R.R. Hill } & 6218 \\ 0753 & \text { R.C. Pate } & 6218 \\ 0753 & \text { H.N. Post } & 6218 \\ 0899 & \text { Technical Library (5) } & 13414 \\ 0619 & \text { Technical Publications } & 13416 \\ 0100 & \text { Document Processing } & \\ & \text { for DOE/OSTI (10) } & 7613-2 \\ 9018 & \text { Central Technical Files } & 8523-2\end{array}$

